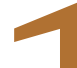 \\ Working Papers 2019
}

The transmission of unconventional monetary policy to bank credit supply: evidence from the TLTRO

António Afonso | Joana Sousa-Leite
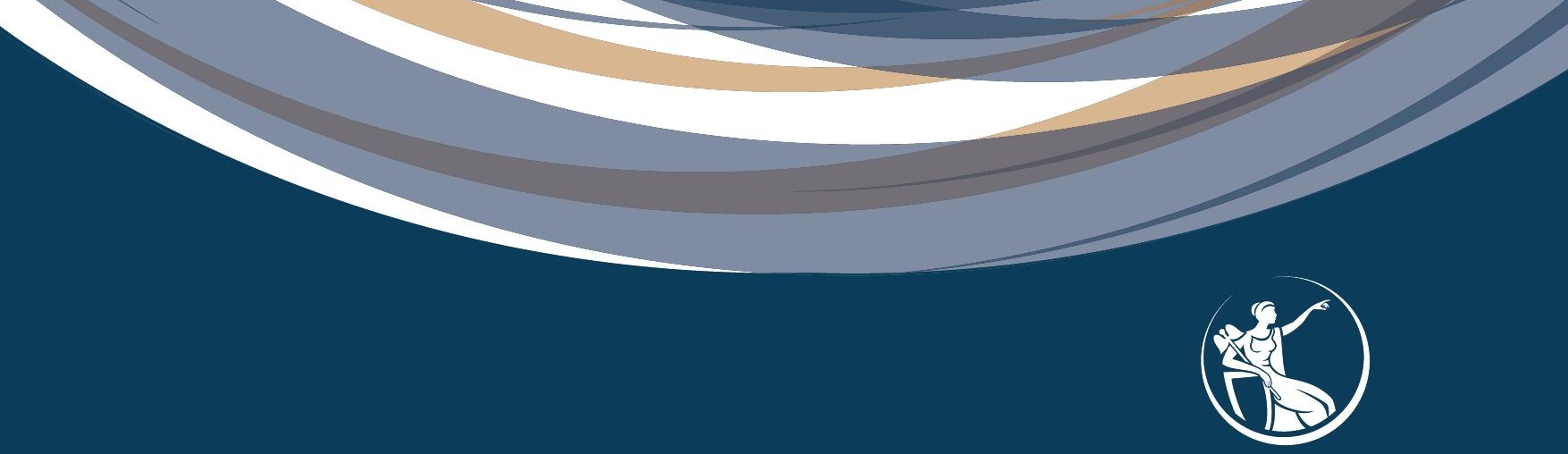



\section{Working \\ Papers 2019}

\section{The transmission of unconventional monetary policy to bank credit supply: evidence from the TLTRO}

António Afonso | Joana Sousa-Leite 
Working Papers | Lisbon 2019 • Banco de Portugal Av. Almirante Reis, 71 | 1150-012 Lisboa • www.bportugal.pt • Edition Economics and Research Department • ISBN (online) 978-989-678-633-5 • ISSN (online) 2182-0422 


\title{
The transmission of unconventional monetary policy to bank credit supply: evidence from the TLTRO
}

\author{
António Afonso \\ REM, UECE \\ ISEG-UL
}

\author{
Joana Sousa-Leite \\ Banco de Portugal \\ ISEG-UL
}

January 2019

\begin{abstract}
We assess the transmission of the Targeted Longer-Term Refinancing Operations (TLTRO) to the bank credit supply for the Euro area (2014:05-2018:01) and for Portugal (2011:01-2018:01), using a panel data setup. For the Euro area, we find a positive relationship between the TLTRO and the amount of credit granted to the real economy. For the vulnerable countries, the effects of the TLTRO on the stock of credit increased from 2016 to 2017. Among the group of small banks, the effects are stronger in less vulnerable countries. We also find that competition has no statistically significant impact on the transmission of the TLTRO to the bank credit supply for the Euro area. For Portugal, using a difference-in-differences model, we find no statistically significant impact of the TLTRO on credit granted by banks. Finally, bidding banks set lower interest rates than non-bidding banks and the difference seems to be larger in 2017. In Portugal, the effects of the TLTRO on loan interest rates also increased from 2016 to 2017 and are stronger for small banks.
\end{abstract}

JEL: C33, C87, E50, E51, E52, E58

Keywords: unconventional monetary policy, TLTRO, credit supply, lending interest rates, bank-lending channel, Euro area, Portugal.

\footnotetext{
Acknowledgements: We are grateful to Diana Bonfim, Jorge Faria Silva and Sónia Félix for very useful comments. The analyses, opinions and findings of this paper represent the views of the authors and they are not necessarily those of the Banco de Portugal or the Eurosystem.

E-mail: aafonso@iseg.utl; jsleite@bportugal.pt
} 


\section{Introduction}

The 2008-2009 Global Financial Crisis (GFC) forced the major Central Banks to implement a set of unconventional monetary policy measures, assumed to have a temporary character (Mishkin, 2011; Roman and Purcel, 2014; Trichet, 2013). These unprecedented measures were aimed at restoring the stability of the financial markets and the correct functioning of the monetary policy transmission mechanism and consisted of liquidity injections via credit refinancing operations at low interest rates, asset purchases from the market in order to lower interest rates, the reduction of monetary policy official interest rates and forward guidance on policy announcements (Acharya et al, 2012; Driffill, 2016; Gertler and Karadi, 2010; Kashyap and Stein, 2000).

Among the unconventional monetary policy measures undertaken by the European Central Bank (ECB) is the so-called quantitative easing (QE), which includes the introduction of the Targeted Longer-Term Refinancing Operations (TLTRO). Such measures, announced on the $5^{\text {th }}$ of June 2014, by the ECB Governing Council, are "designed to enhance the functioning of the monetary policy transmission mechanism by supporting bank lending to the real economy" (Draghi, 2014a).

Specifically, we study the transmission of the TLTRO to the bank credit supply, in order to assess if the liquidity obtained from these operations has met the essence of its main goal, namely if banks have used this liquidity to increase the credit granted to the real economy. To measure the impact of the TLTRO, we estimate the impact of these operations on the credit granted by the banking sector to the real economy. Our study encompasses two analyses: an analysis for the Euro area, studying the impact on the amount of bank credit supply and a more detailed analysis for Portugal, considering not only the amounts but also the cost of credit.

For the Euro area analysis, we assess the transmission of the TLTRO to the amount of credit granted to the real economy. To do so, we study the evolution of the stock of credit between the $30^{t h}$ of April 2014 and the $31^{\text {st }}$ of January 2018, using an OLS empirical regression with bank fixed effects. First, we find a positive association between the TLTRO and the amount of credit granted to the real economy for vulnerable countries in 2016 and 2017, showing that the TLTRO had a positive and significant impact on the stock of credit, which means that banks in vulnerable countries used part of the money borrowed in the TLTRO to grant credit to the real economy in these years. Moreover, for the group of small banks, we find that the TLTRO had a higher impact in less vulnerable countries, showing that the transmission of the monetary policy was more effective in these countries. Second, we assess how competition in the banking sector affects the transmission of the TLTRO to the stock of credit, using the Herfindahl Index of market concentration per country. According to the results, there is no statistically significant relationship between market 
concentration in the banking sector and the transmission of the TLTRO to the bank credit supply.

For the specific case of Portugal, we consider the period between 2011 and 2018 and estimate the transmission of the TLTRO to the amount of credit granted to the real economy and the pass-through of its favourable interest rates to bank loan interest rates. We use a difference-in-differences OLS regression with bank and time fixed effects, introducing a control group composed by the monetary policy counterparties that did not participate in the TLTRO. Our results suggest that there is no statistically significant association between the TLTRO and the amount of credit granted to the real economy. In contrast, we find a negative and statistically significant impact of the TLTRO on the cost of credit in 2016 and 2017. In 2017, interest rates of loans granted by treated banks are on average, approximately, 1.67 basis points lower relative to control banks and the effects of the TLTRO on the cost of credit have increased from 2016 to 2017. Also, the difference between treated and control banks is higher for the group of small banks, indicating that the transmission of the TLTRO to the cost of credit was stronger for these banks. The results on the transmission of the TLTRO to loan interest rates suggest a correct functioning of the monetary policy transmission mechanism. Therefore, the results demonstrate that the TLTRO have contributed to the well-functioning of the monetary policy transmission mechanism.

Hence, our contribution to the literature includes notably: i) the effects of the unconventional monetary policy on the amount of bank credit supply; ii) the pass-through of the Central Bank borrowing rate to the real economy lending interest rates in Portugal; iii) the analysis of the relation between competition in the banking sector and monetary policy in the Euro area.

The remainder of the paper is organised as follows. Section 2 describes the background of the TLTRO. Section 3 reviews the related literature. Section 4 summarises the data. Section 5 explains the methodology used to perform this analysis. Section 6 presents the empirical results. Section 7 concludes.

\section{Background}

\subsection{Unconventional monetary policy measures}

Following the GFC, the ECB implemented the first unconventional monetary policy measures, including the fixed-rate full allotment (FRFA) in the Open Market Operations (OMO), meaning that under an interest rate fixed by the ECB, considering that counterparties have enough eligible collateral available, their bids are fully satisfied, a new LTRO with one-year maturity (1-year LTRO) and the first purchase programme of covered bonds (CBPP1). In 2010, with the sovereign debt crisis in several Euro area countries, the ECB introduced the first purchase programme of public and private debt securities, 
the Securities Market Programme (SMP). Between 2011 and 2012, with the intensification of the sovereign debt crisis, the ECB implemented the second purchase programme of covered bonds (CBPP2), two new LTRO with threeyear maturity (3-year LTRO), reduced the minimum reserve requirement coefficient from $2 \%$ to $1 \%$, lowered the interest rate on the deposit facility to $0 \%$ and announced the Outright Monetary Transactions (OMT) programme. Moreover, regarding the eligible collateral in the OMO, the compliance with the minimum rating level was suspended in the case of securities issued or guaranteed by the Government and bank loans (additional bank loans on individual and aggregated bases) started to be accepted (Banco de Portugal, 2017).

In 2014, the Euro deflation crisis led the ECB to implement a new set of unconventional monetary policy measures, the so-called QE, which included the establishment of a negative interest rate on the deposit facility, the Expanded Asset Purchase Programme (APP), consisting in four purchase programmes: Asset-Backed Securities (ABSPP), Covered Bonds (CBPP3), Public Sector Debt (PSPP) and Corporate Sector Debt (CSPP) and the TLTRO. Along with this set of measures, forward QE guidance was disclosed to the market, not only on the ECB official interest rates, expected to remain at low levels for a considerable period of time, but also on the ECB willingness to increase the extent and/or the duration of APP, in case a less favourable outlook would occur or an unwarranted tightening of the financial conditions would arise. These unconventional measures, besides injecting liquidity in the economy, were also implemented to achieve the main ECB goal of an inflation rate below, but close to, 2\% over the medium term (Banco de Portugal, 2017; Draghi, 2014b; $\mathrm{ECB} / 2015 / 10)$.

The unconventional monetary policy measures were responsible for containing sovereign yield spreads, in relation to German yields, for the Euro area, after the 2008-2009 GFC and the 2010 sovereign debt crisis (Afonso and Kazemi, 2018). Besides that, these measures resulted in the expansion of the ECB balance sheet, reducing the responsiveness of the sovereign yield spreads to their fundamental determinants (Afonso et al, 2018).

\subsection{Targeted Longer-Term Refinancing Operations (TLTRO)}

The TLTRO are longer-term refinancing operations, with the specific target of supporting the bank lending to the real economy, contributing to the wellfunctioning of the monetary policy transmission mechanism (Draghi, 2014a). The amounts that credit institutions can borrow on these operations are linked to their eligible credit granted to both non-financial corporations and households ${ }^{1}$, excluding lending for house purchase, in all currencies, for the

1. Households include non-profit institutions serving households. 


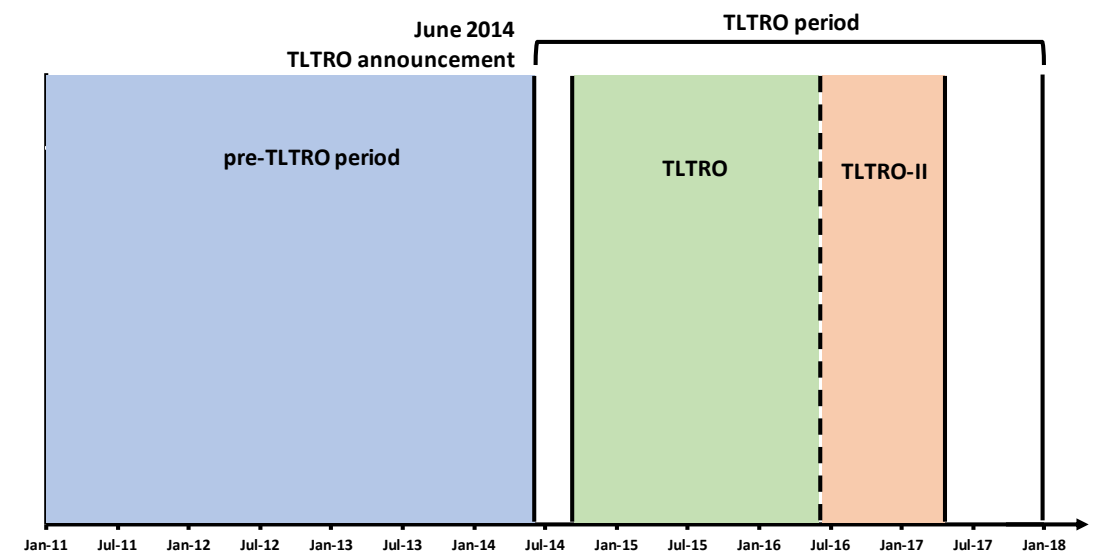

FIgURE 1: Timeline of the analysis (pre-TLTRO and TLTRO periods)

Source: ECB and authors' calculations.

Euro area residents. Banks either were able to participate in these operations individually or associated in a banking group, domestic or cross-border. In the case of a cross-border banking group, the lead institution participates in the TLTRO based on the eligible net lending of all banks included in the group, allocating all the credit granted by the banks incorporated in the group to the jurisdiction of the lead institution (ECB, 2014).

The TLTRO had two series: the first one, announced on the $5^{\text {th }}$ of June 2015 and implemented between the $24^{\text {th }}$ of September 2014 and the $29^{\text {th }}$ of June 2016, through 8 quarterly operations, where the interest rate was indexed to the Main Refinancing Operation (MRO) at the settlement date and the second series, announced on the $10^{\text {th }}$ of March 2016 and implemented between the $29^{\text {th }}$ of June 2016 and the $29^{\text {th }}$ of March 2017 (TLTRO-II), through 4 quarterly operations, as illustrated in Figure 1. For the second series, the interest rate applied was dependent on the evolution of the net lending from the $1^{\text {st }}$ of February 2015 to the $31^{\text {st }}$ of January 2018, ranging from a minimum equivalent to the deposit facility rate at the bidding date $(-0.4 \%)$ to a maximum of the MRO rate (0\%) (ECB/2014/34; ECB/2016/10).

The two series of the TLTRO injected a total amount of EUR 1172 billion in the Euro area banks, through 849 banks representing $46 \%$ of the Euro area banking system, assessed by its total assets. Although the second series has provided EUR 740 billion, the total net injection was only EUR 336 billion, due to the substitution effect between the two, profiting from a better interest rate of the second series. As illustrated in Figure 2, in the end of 2017, the outstanding 


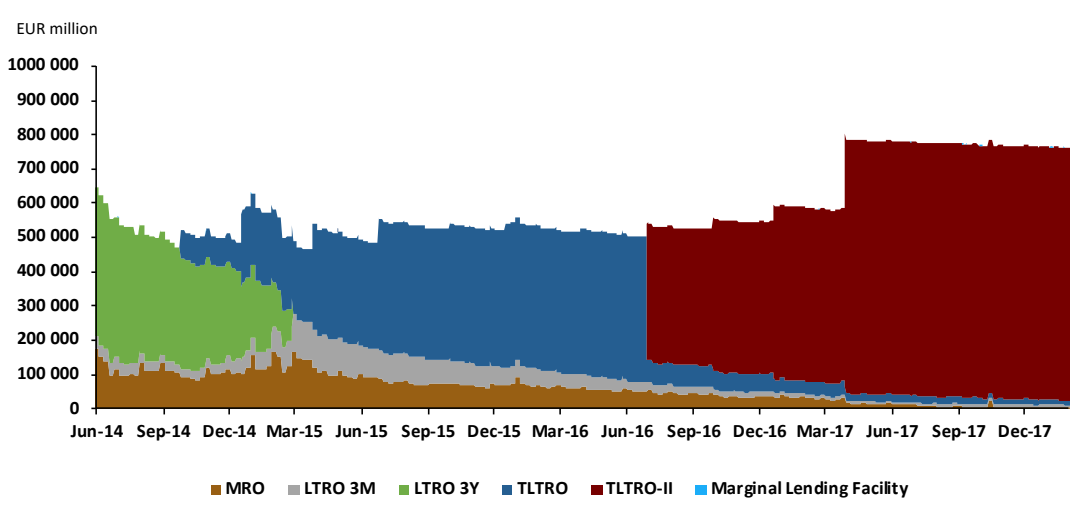

FiguRE 2: Evolution of monetary policy refinancing operations for the Euro area Source: ECB and authors' calculations.

amount of the TLTRO represents around $99 \%$ of the total outstanding amount of the OMO.

In addition, specifically in Portugal, the TLTRO have injected a total amount of EUR 33 billion, through 17 banks. The second series has also had a higher demand, providing EUR 21 billion, albeit the net injection was only EUR 10 billion, considering the substitution effect between TLTRO and TLTRO-II. Similarly, as Figure 3 illustrates, in the end of 2017, the outstanding amount of the TLTRO represents the total outstanding amount borrowed by Portuguese counterparties in the OMO.

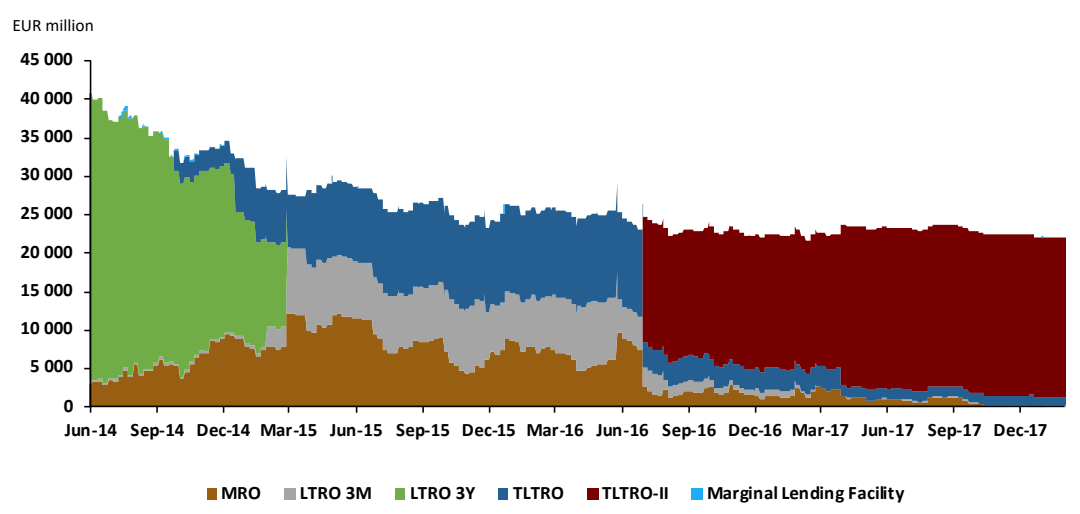

FiguRE 3: Evolution of monetary policy refinancing operations for Portugal Source: Banco de Portugal and authors' calculations. 


\section{Literature}

The effects of the TLTRO have not yet been largely studied in the existing literature, mostly due to the recent character of these operations. However, the 3 -year LTRO, implemented between the $21^{\text {st }}$ of December 2011 and the $29^{\text {th }}$ of February 2012, have already been the object of several academic researches. These operations have provided EUR 1019 billion to 800 Euro area banks and were described as "credit support measures to support bank lending and liquidity in the Euro area money market" (ECB/2012/18).

When analysing the effects of the 3-year LTRO, using a panel-VAR (vector autoregression) for the Euro area countries with information from the Bank Lending Survey (BLS), Darracq-Paries and Santis (2013) concluded that 3year LTRO gave a significant contribution to the improvement of the real GDP projections and to the credit granted to non-financial corporations, supporting the provision of bank lending and avoiding a sudden dry-up of credit supply. Nevertheless, the authors also analyse the transmission to the real economy, concluding that 3-year LTRO seem to have resulted more in a quantitative credit easing than in a lower cost of financing.

Carpinelli and Crosignani (2017) show that banks exposed to the foreign wholesale market reduced their credit supply during the period of funding stress and restored their credit supply once the Central Bank injected liquidity into the system through the 3-year LTRO, albeit a significant fraction of the Central Bank liquidity was used to increase holdings of high-yield securities, mainly for the banks less affected by the wholesale funding dry-up, using the funds to reach-for-yield.

In addition, Andrade et al (2015) study the impact of the 3-year LTRO in France and concluded that banks seized the opportunity to replace their short-term financing with a longer-term Central Bank borrowing, showing that 3 -year LTRO worked via the bank lending channel when banks were financially constrained, allowing an increase on their lending to firms with intensive margin by the use of their 3-year LTRO uptakes. Jasova et al (2018) analyse the impact of the 3-year LTRO in Portugal and show that its extended maturity had a positive and economically sizable impact on the credit granted to the real economy. Additionally, the authors also show that 3-year LTRO had a policy side effect, as banks used this liquidity to purchase more securities and therefore partially replaced the lending to the real economy.

In June 2014, the ECB announced the TLTRO, with the specific target of supporting the credit granted by the banking system. These operations were specifically designed to give banks the incentive to increase loans to nonfinancial corporations and households (except lending for house purchase), since the borrowing limits of these collateralised cash loans were a function of their net lending. In the TLTRO-II, not only the borrowing limits but also its interest rate depended on their net lending, what contributes to a better functioning of the monetary policy transmission mechanism (ECB/2016/10). 
In fact, the conditions of the TLTRO are a key aspect for its success. For instance, banks seem to prefer a longer-term refinancing rather than a roll-over of short-term monetary policy refinancing operations, not only due to the uncertainty on the maintenance of the FRFA in the OMO over the subsequent years, but also for regulatory reasons, for instance longer-term operations contributes to the fulfilment of the net stable funding ratio (NSFR) (Renne, 2014).

When analysing the BLS, addressed to a representative sample of Euro area banks in order to improve the knowledge of the Euro area bank lending behaviour, we concluded that responses are quite similar for both series of TLTRO (TLTRO and TLTRO-II). Among the reasons presented by the Euro area banks to participate in these longer-term operations, the most commonly referred was its attractive conditions (profitability motive), along with the reduction of the current difficulties and/or the prevention of future ones (precautionary motive) and, in a small extent, the enhancement of the regulatory liquidity requirements fulfilment (namely the NSFR). On the other hand, Euro area banks indicated the absence of fund constraints as the main reason for not participating in TLTRO, but also the concerns about insufficient loan demand (the fulfilment of the required TLTRO net lending benchmark), capital and collateral constraints, as well as concerns about market stigma. The Euro area banks that participated in the TLTRO used the funds to grant loans to non-financial corporations and households, to substitute maturing debt and interbank lending, as well as to replace other Eurosystem refinancing operations, namely the 3-years LTRO. Banks indicated that the TLTRO contributed to the improvement of not only the credit supply, but also its terms and conditions, especially for non-financial corporations (ECB, 2017a; ECB, 2017b).

Balfoussia and Gibson (2015) conclude that there is a significant impact of the TLTRO on the real economy activity, both for the Euro area as a whole and for the specific case of Greece, via an easing of the financial conditions, affecting several real economy indicators, verified as positive and significant, and possibly resulting in an overall economic growth increase. The authors used a financial conditions index (FCI) developed by Angelopoulou et al (2013), which includes a wide range of prices, quantities, spreads and survey data, in line with the economic theory followed by the authors, combined with a VAR framework, in order to estimate the potential impact of TLTRO on several economic activity aspects.

Benetton and Fantino (2018) estimate the effects of the TLTRO on the price of credit for Italy, concluding that bidder banks lowered their loan interest rates by, approximately, 20 basis points relative to the banks that did not participate in these operations. The authors also show that market concentration reduces the pass-through of the TLTRO to firms through the cost of credit. 
In 2017, the ECB presented two Economic Bulletins, including the evolution of both the amounts and lending interest rates of the credit granted to nonfinancial corporations, for the Euro area, showing that the two series of TLTRO have resulted in more attractive credit conditions. Bidder banks located in vulnerable countries have lowered their interest rates more than banks that did not participate in these operations (non-bidders). Therefore, vulnerable countries had a stronger response to the TLTRO than less vulnerable ones, which contributed to a lower dispersion of bank lending interest rates, resulting in a reduction of the fragmentation of the Eurosystem financing conditions. Additionally, banks with high levels of excess liquidity verified significant increases in credit volumes (ECB, 2017c). For less vulnerable countries, the stock of credit has increased for bidder banks and was kept relatively stable for non-bidders. In the case of vulnerable countries, non-bidder banks verified a significant decrease in intermediation amounts, while, for bidders, the decline was smoother (ECB, 2017d).

Therefore, our work contributes to three strands of literature. First, we study the transmission of monetary policy to credit supply (Agarwal et al, 2015; Jiménez et al, 2012; Jiménez et al, 2014), in particular the effects of the unconventional monetary policy on the amount of credit supply (Chakraborty et al, 2016; Chodorow-Reich, 2014; Di Maggio et al, 2014; Khwaja and Mian, 2008). We aim at assessing how a positive funding shock, namely a Central Bank liquidity injection, impacts the credit supply of banks (Andrade et al, 2015; Carpinelli and Crosignani, 2017; Schnabl, 2012). Second, for the Portuguese case we study the pass-through of the Central Bank borrowing rate to the real economy lending interest rates (Benetton and Fantino, 2018; Cottarelli et al, 1995; van Leuvensteijn et al, 2008). Finally, for the Euro area we analyse the relation between competition and monetary policy (Berger and Hannan, 1989; de Graeve et al, 2007; Neumark and Sharpe, 1992), in particular the relation between market concentration and the transmission of monetary policy.

\section{Data}

To perform our analysis at the Euro area level, we used confidential data on credit granted by bank or banking group to non-financial corporations and households, excluding lending for house purchase, for all the Euro area countries. These data include the initial outstanding amount of credit and quarterly net lending amounts, which allowed us to calculate eligible stock of credit by quarter. Moreover, we also included confidential data about the participation in the TLTRO and early repayments by bank or banking group.

These data consist of individual loan-level bank information between the $30^{\text {th }}$ of April 2014 and the $31^{\text {st }}$ of January 2018, for the 19 countries of the Euro area: Austria (AT), Belgium (BE), Cyprus (CY), Germany (DE), Estonia (EE), Spain (ES), Finland (FI), France (FR), Greece (GR), Ireland (IE), Italy (IT), 


\begin{tabular}{|c|c|c|c|c|c|}
\hline \multirow[b]{2}{*}{ VARIABLES } & \multicolumn{5}{|c|}{ EURO AREA } \\
\hline & Obs & Mean & Std.Dev. & Min & Max \\
\hline Stock of credit (EUR million) & 9337 & 4919 & 14902 & 19 & 104056 \\
\hline TLTRO (EUR million) & 9337 & 656 & 2924 & 0 & 60920 \\
\hline Herfindahl Index & 9337 & 0.049 & 0.044 & 0.025 & 0.363 \\
\hline TLTRO*HerfindahI Index & 9337 & 45 & 209 & 0 & 3786 \\
\hline Total assets (EUR million) & 9337 & 31719 & 147420 & 37 & 2077758 \\
\hline Loans over assets ratio (\%) & 9337 & 59.7 & 15.4 & 3.2 & 95.3 \\
\hline Bad loans over loans ratio (\%) & 9337 & 5.7 & 9.5 & 0.0 & 81.8 \\
\hline Capital ratio (\%) & 8650 & 14.5 & 4.9 & 0.5 & 145.6 \\
\hline
\end{tabular}

TABLE 1. Descriptive statistics for all the Euro area countries

Source: ECB, Moody's Analytics and authors' calculations.

Lithuania (LT), Luxembourg (LU), Latvia (LV), Malta (MT), Netherlands (NL), Portugal (PT), Slovenia (SI) and Slovakia (SK). For the first series of TLTRO, the data were reported on a quarterly basis (from the $30^{\text {th }}$ of April 2014 to the $30^{\text {th }}$ of April 2016), albeit for the second series, banks had only two reporting periods (from the $1^{\text {st }}$ of February 2015 to the $31^{\text {st }}$ January 2016 and from the $1^{\text {st }}$ of February 2016 to the $31^{\text {st }}$ January 2018). Therefore, for the latter period, as we only had the initial stock and the net lending during the period, we divided the eligible net lending into quarters to construct the quarterly panel, assuming the growth of the stock of credit was linear during the period.

For the control variables, we used the Moody's Analytics BankFocus database that provides year-end data, by bank, for the chosen variables: total assets value, loans over assets ratio, bad loans over loans ratio and capital ratio (Common Equity Tier 1 ratio, included in Capital Requirements Directive 2013/36/EU and Common Requirements Regulation 575/2013, transposed to the European Union from the Basel III global standards on bank capital).

In total, 849 banks and banking groups participated in the TLTRO. However, there are some considerations regarding the composition of the final sample. For instance, bidder banks that have been merged or acquired by another bidder bank during the period under analysis were integrated in the respective merging or acquiring bank, since the outstanding amounts of the TLTRO were transferred to the new owner in these cases. Additionally, banks that did not have available information for the control variables, for example branches that participated through the National Central Bank (NCB) of its location, but its financial statement is integrated in the financial statement of its headquarters, were withdrawn from the sample. Moreover, banks that went 


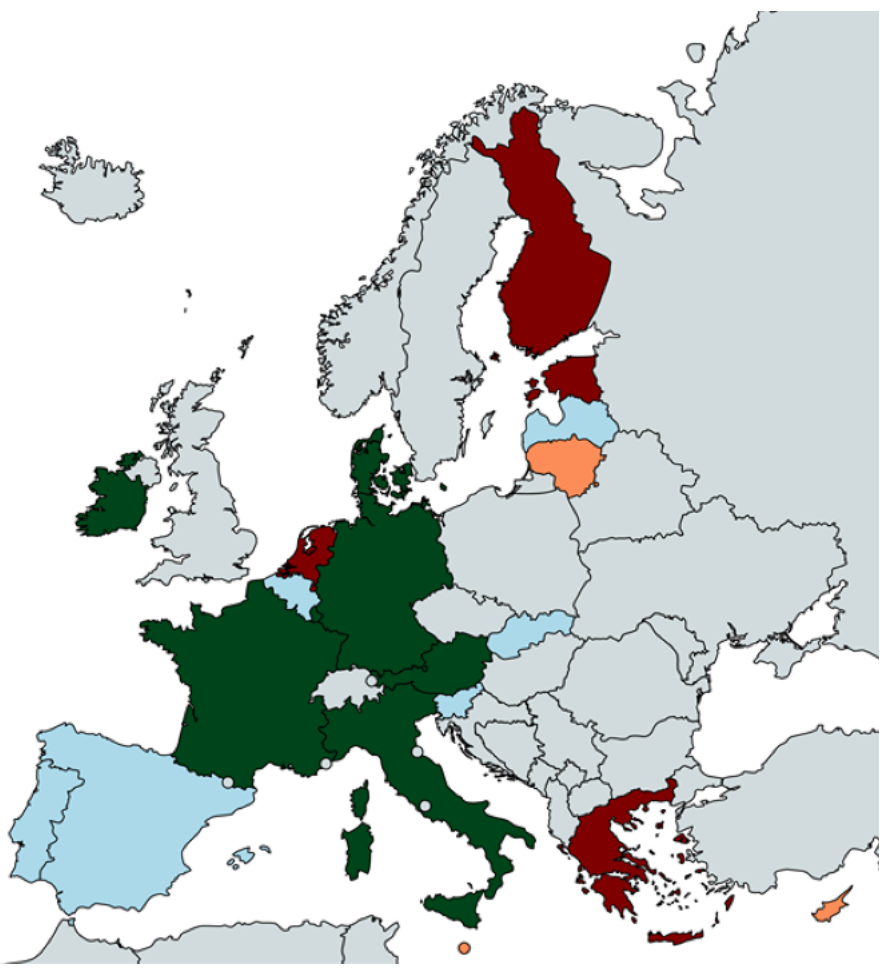

Figure 4: Geographical distribution of the Herfindahl Index

Source: ECB and authors' calculations.

bankrupt during this period were kept in the sample, albeit with data only up to the date of the bankruptcy. Lastly, the final sample has 749 banks.

Table 1 shows the descriptive statistics of the variables included in the dataset. The dependent variable is the natural logarithm of the stock of credit, granted by bank b at time t. The stock of credit was on average around EUR 4 919 million, although the dataset includes amounts of credit between EUR 19 and 104056 million. The stock of credit variable was winsorised at $1 \%$ level, to account for the outliers in the sample.

The average outstanding amount in the TLTRO was EUR 656 million. During the 12 operations in total of both TLTRO and TLTRO-II, several banks have repaid in advance some of the borrowed amounts, for various motives, such as the more attractive interest rates applied to the last operations when compared to the first ones. For this reason, we used the outstanding amounts instead of the total take-up.

The Herfindahl Index refers to the market concentration and was obtained by summing the squares of the market shares of all the credit institutions in the banking sector of the country. The exact formula according to which 


\begin{tabular}{|c|c|c|c|c|c|c|}
\hline \multirow[b]{3}{*}{ VARIABLES } & \multicolumn{6}{|c|}{ EURO AREA } \\
\hline & \multicolumn{3}{|c|}{ LESS VULNERABLE COUNTRIES } & \multicolumn{3}{|c|}{ VULNERABLE COUNTRIES } \\
\hline & Obs & Mean & Std.Dev. & Obs & Mean & Std.Dev. \\
\hline Stock of credit (EUR million) & 6527 & 3200 & 11398 & 2810 & 8028 & 18479 \\
\hline TLTRO (EUR million) & 6527 & 348 & 1802 & 2810 & 1290 & 4340 \\
\hline Herfindahl Index & 6527 & 0.041 & 0.045 & 2810 & 0.068 & 0.036 \\
\hline TLTRO*HerfindahI Index & 6527 & 23 & 141 & 2810 & 96 & 307 \\
\hline Total assets (EUR million) & 6527 & 25479 & 143000 & 2810 & 35000 & 132000 \\
\hline Loans over assets ratio (\%) & 6527 & 61.3 & 14.9 & 2810 & 56.2 & 15.9 \\
\hline Bad loans over loans ratio (\%) & 6527 & 2.4 & 3.6 & 2810 & 13.5 & 13.5 \\
\hline Capital ratio (\%) & 6112 & 14.4 & 4.4 & 2538 & 14.8 & 5.7 \\
\hline
\end{tabular}

TABLE 2. Descriptive statistics for the Euro area vulnerable and less vulnerable countries

Source: ECB, Moody's Analytics and authors' calculations.

banks must report the data to the ECB is described in the ECB Guideline on monetary and financial statistics (ECB/2014/15) ${ }^{2}$. The credit market in the Euro area is quite competitive, as the average value of the index is 0.049 , with values ranging between 0.025 and 0.363 , as illustrated in Figure 4.

Finally, we used the main structural characteristics of the banks as control variables. Banks had on average EUR 31719 million of total assets, about $59.7 \%$ of the total assets being loans, from which $5.7 \%$ are bad loans (impaired or non-performing loans), representing quite a low risk of the credit portfolio. The capital adequacy is measured by the capital ratio, according to the Basel III rules, which is on average $14.5 \%$.

As the data are confidential at country level, we aggregated it, classifying the countries into two groups, according to ECB Economic Bulletins approach (ECB, 2017c; ECB, 2017d): vulnerable (CY, ES, GR, IE, IT, PT and SI) and less vulnerable (AT, BE, DE, EE, FI, FR, LT, LU, LV, MT, NL and SK) countries. The descriptive statistics of the variables included in the dataset for the two groups of countries are presented in Table 2 .

2. The Herfindahl Index is obtained by summing the squares of the market shares of all the Credit Institutions (CI) in the banking sector and must be reported to the ECB in accordance with the following formula: $\mathrm{HI}=\sum_{i=1}^{n}\left(\frac{X_{i}}{X}\right)^{2}$, where $\mathrm{n}$ is the number of CI in the country, $X_{i}$ represents the total assets of $C I_{i}$ and $\mathrm{X}=\sum_{i=1}^{n}\left(X_{i}\right)$ represents the total assets of all CI of the country 


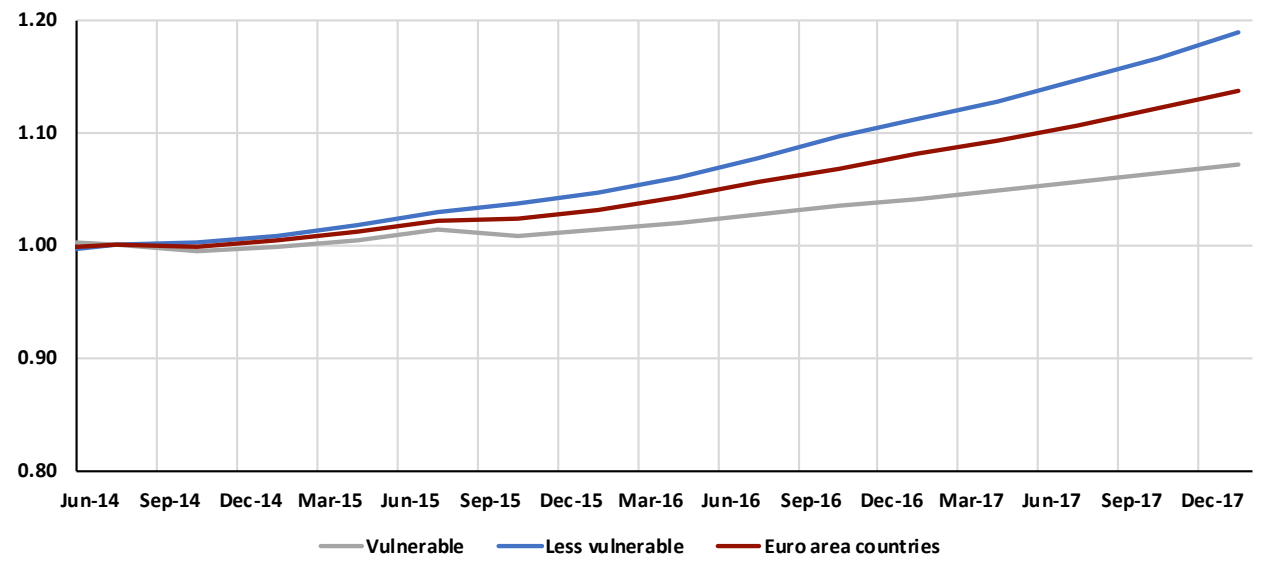

Figure 5: Evolution of the stock of credit for the Euro area countries

Source: ECB and authors' calculations.

Figure 5 shows the evolution of bank lending to non-financial corporations and households (except lending for house purchase), using an index equal to 1 in June 2014, prior to the announcement of the TLTRO.

Overall, Euro area banks increased the amount of credit granted by $14 \%$ since June 2014. However, while in less vulnerable countries bank lending has increased by $19 \%$ since June 2014, in vulnerable countries the growth was only by $7 \%$ in the same period.

We also performed a more detailed analysis for Portugal, using Balance Sheet Information (BSI) and Monetary Interest Rate (MIR) databases reported by the Portuguese banks to the Statistics Department of Banco de Portugal. The data consist of individual loan-level bank information, between the $1^{\text {st }}$ of February 2011 and the $31^{\text {st }}$ of January 2018, for all the monetary policy counterparties established in Portugal. The sample was restricted to the monetary policy counterparties, instead of all banks, because only these banks have had access to the TLTRO. These data include monthly outstanding amounts of credit, adjustments to loan sales and purchases, as well as other loan transfers, plus other adjustments (currency revaluations, write-offs/writedowns and credit reclassifications), which allowed us to calculate eligible stocks of credit and net lending amounts for the TLTRO. Additionally, we study if the financing conditions have improved during the period of the TLTRO, using the loan rates applied to new credit operations (annualised agreed rate). 


\begin{tabular}{lcccrr}
\hline & \multicolumn{5}{c}{ PORTUGAL } \\
\cline { 2 - 6 } VARIABLES & Obs & Mean & Std.Dev. & Min & Max \\
\hline Stock of credit (EUR million) & 2762 & 3580 & 6682 & 1 & 26660 \\
\hline Interest Rate (\%) & 2762 & 3.8 & 3.3 & 0.1 & 16.2 \\
TLTRO (EUR million) & 2762 & 204 & 746 & 0 & 6410 \\
\hline Total assets (EUR million) & 2762 & 13452 & 26458 & 37 & 118000 \\
Loans over assets ratio (\%) & 2762 & 60.99 & 23.36 & 5.698 & 99.857 \\
Bad loans over loans ratio (\%) & 2762 & 4.7 & 6.2 & 0.0 & 109.7 \\
Government bonds over assets ratio (\%) & 2762 & 16.3 & 23.9 & 0.0 & 139.4 \\
\hline
\end{tabular}

TABle 3. Descriptive statistics for the Portuguese banks

Source: Banco de Portugal and authors' calculations.

For the case study of Portugal, we introduced a control group composed by the monetary policy counterparties that did not participate in the TLTRO and a period before the implementation of these operations. Thus, we compared the evolution of both the amounts of credit granted and the cost of credit applied by bidder banks (treated group) and non-bidder banks (control group), for the periods before (from February 2011 to May 2014) and after the announcement of the TLTRO (from June 2014 to January 2018). The descriptive statistics of the variables in the dataset for all the monetary policy counterparties are presented in Table 3.

Table 4 shows the descriptive statistics of the variables included in the dataset, comparing the banks that have participated in at least one TLTRO operation (treated) with the other banks (control), in the periods before and after the announcement of the TLTRO in June 2014. The dependent variable is the natural logarithm of the stock of credit, granted by bank b at time $t$. The stock of credit and the interest rates variables were winsorised at $1 \%$ level, to account for the presence of outliers in the sample.

The stock of credit decreased, on average, between the periods before and after the TLTRO, for both groups, although the reduction in relative terms was higher in the control group (30\% comparing with $8 \%$ for the treated group). The interest rate was, on average, higher in the treated group, mainly due to the characteristics of the participant banks, but decreased in both groups between the two periods. The 17 Portuguese banks that participated in the TLTRO had, on average, EUR 752 million of outstanding amount in the TLTRO.

The treated group is, on average, composed by larger banks (EUR 22770 million of total assets) than control group (EUR 1359 million of total assets), although the other bank specific characteristics are quite similar. 


\begin{tabular}{|c|c|c|c|c|c|c|}
\hline \multirow[b]{3}{*}{ VARIABLES } & \multicolumn{6}{|c|}{ PORTUGAL } \\
\hline & \multicolumn{3}{|c|}{ Treated } & \multicolumn{3}{|c|}{ Control } \\
\hline & Obs & Mean & Std.Dev. & Obs & Mean & Std.Dev. \\
\hline \multicolumn{7}{|l|}{ Before } \\
\hline Stock of credit (EUR million) & 680 & 6914 & 8951 & 640 & 463 & 518 \\
\hline Interest Rate (\%) & 680 & 6.1 & 3.9 & 640 & 3.8 & 3.4 \\
\hline TLTRO (EUR million) & 680 & 0 & 0 & 640 & 0 & 0 \\
\hline Total assets (EUR million) & 680 & 26628 & 36722 & 640 & 1674 & 2034 \\
\hline Loans over assets ratio (\%) & 680 & 58.9 & 16.2 & 640 & 67.9 & 26.2 \\
\hline Bad loans over loans ratio (\%) & 680 & 4.4 & 3.5 & 640 & 5.1 & 7.8 \\
\hline Government bonds over assets ratio (\%) & 680 & 15.1 & 18.9 & 640 & 10.6 & 21.2 \\
\hline \multicolumn{7}{|l|}{ After } \\
\hline Stock of credit (EUR million) & 748 & 6332 & 7582 & 694 & 325 & 374 \\
\hline Interest Rate (\%) & 748 & 3.5 & 2.8 & 694 & 2.0 & 2.2 \\
\hline TLTRO (EUR million) & 748 & 752 & 1282 & 694 & 0 & 0 \\
\hline Total assets (EUR million) & 748 & 22770 & 29264 & 694 & 1359 & 1501 \\
\hline Loans over assets ratio (\%) & 748 & 57.2 & 16.5 & 694 & 60.7 & 30.4 \\
\hline Bad loans over loans ratio (\%) & 748 & 4.9 & 4.5 & 694 & 4.6 & 7.8 \\
\hline Government bonds over assets ratio (\%) & 748 & 17.1 & 15.8 & 694 & 21.8 & 34.4 \\
\hline
\end{tabular}

TABLE 4. Descriptive statistics for the Portuguese treated and control banks

Source: Banco de Portugal and authors' calculations.

Besides the improved financial conditions offered to the Euro area banks, TLTRO have been designed to pass its favourable borrowing conditions to the credit granted to non-financial corporations and households. Figures 6 and 7 depict the aggregate evolution for the group of banks that have borrowed from TLTRO and/or TLTRO-II (bidders) and the group of banks that have accessed neither of the two (non-bidders).

Figure 6 shows the evolution of the credit granted to non-financial corporations and households (except lending for house purchase), using an index equal to 1 in June 2014, the announcement of the TLTRO. For the Portuguese banks, TLTRO seem to have prevented the slowdown in credit volumes visible in non-bidder banks. Therefore, bidder banks broadly maintained the stock of credit between June 2014 and January 2018, while non-bidder banks decreased the stock of credit by, approximately, $41 \%$.

Due to the benefits associated with these operations, banks had the incentive to increase the amount of credit granted to the real economy, which has also led to interest rates that are more favourable. The evidence suggests that bidder banks lowered their loan interest rates by more than non-bidder banks, as Figure 7 shows. Although non-bidders presented, on average, lower 


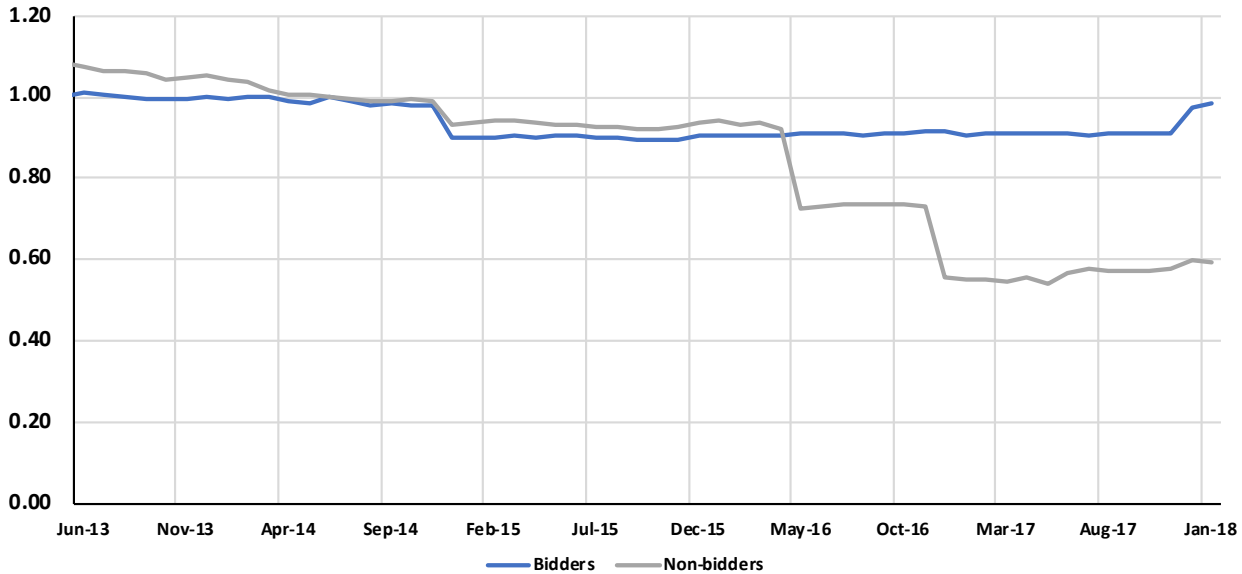

FiguRE 6: Evolution of the stock of credit for the Portuguese treated and control banks Source: Banco de Portugal and authors' calculations.

interest rates in the beginning of the TLTRO compared to bidder banks, the decrease in loan interest rates during the period under analysis was only by 1.3 basis points, while bidder banks decreased their loan interest rates by 2.7 basis points since June 2014.

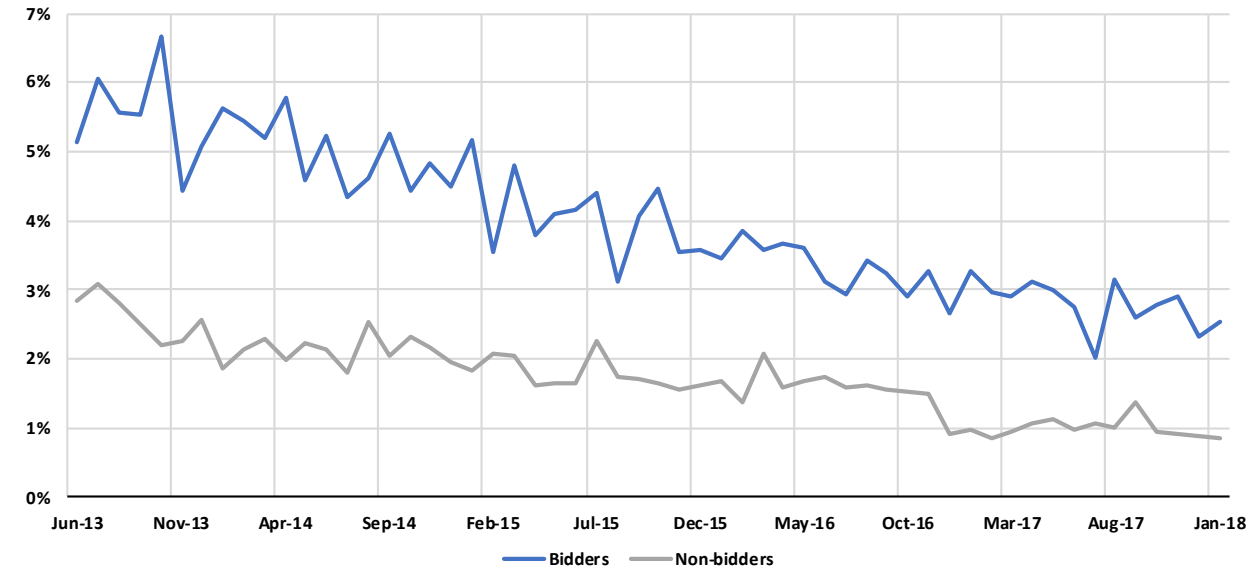

Figure 7: Evolution of loan interest rates for the Portuguese treated and control banks Source: Banco de Portugal and authors' calculations. 


\section{Methodology}

\subsection{Euro area}

To analyse the data, we use a panel data approach. We construct a quarterly balanced panel for 749 banks and 15 periods, between the $30^{\text {th }}$ of April 2014 and the $31^{\text {st }}$ of January 2018. Panel data has several advantages relevant to our empirical analysis, as it allows for more information, more variability, less collinearity, more degrees of freedom and more efficiency (Baltagi, 2005).

We include time varying coefficients to capture the dynamics of the transmission of the TLTRO to the credit granted and clustered the standard errors by bank:

$$
L_{b, c, t}=\alpha+\lambda_{b}+\sum_{T} \beta_{T} \Phi_{T=t} T L T R O_{b, T}+\theta X_{b, c, t-1}+\epsilon_{b, c, t}
$$

where $L_{b, c, t}$ is the natural logarithm of the stock of credit, granted by bank b, in country c, in period t, TLTRO $O_{b, t}$ is the natural logarithm of the TLTRO outstanding amount of bank b at quarter t, $\lambda_{b}$ are bank fixed effects, $\Phi_{T=t}$ is a dummy variable equal to 1 when $\mathrm{t}$ corresponds to year $\mathrm{i}(\mathrm{i}=2014,2015,2016$, $2017)$ and $\epsilon_{b, c, t}$ is an error term. These variables were also complemented with control variables, deemed relevant to explain net lending, as each bank has its own individual characteristics affecting the dependent variable. Hence, $X_{b, c, t-1}$ are bank controls ${ }^{3}$, specifically the value of total assets, the loans over assets ratio, the bad loans over loans ratio and the capital ratio.

To identify how the competition in the banking sector affects the transmission of the TLTRO to the stock of credit, we add an interaction term to equation (1):

$$
\begin{aligned}
L_{b, c, t}= & \alpha+\lambda_{b}+\sum_{T} \beta_{T} \Phi_{T=t} \operatorname{TLTRO}_{b, T} \\
& +\sum_{T} \beta_{T} \Phi_{T=t} T L T R O_{b, T} H I_{c}+\theta X_{b, c, t-1}+\epsilon_{b, c, t}
\end{aligned}
$$

where the $H I_{c}$ is the Herfindahl Index for credit institutions in country c. The interaction between $T L T R O_{b, t}$ and $H I_{c}$ measures the effects of the competition on the transmission of the unconventional monetary policy to the real economy. We also included bank fixed effects, in order to control for time-invariant unobserved heterogeneity at bank level.

\subsection{Portugal}

To analyse the data for Portugal, we construct a monthly balanced panel for 35 banks and 84 periods, between the $1^{\text {st }}$ of February 2011 and the $31^{\text {st }}$ of January

3. Data are in an annual basis. The amounts relate to the year-end prior to quarter t. 
2018. We performed two distinct analyses: the transmission of the TLTRO to the stock of credit and to the cost of credit. However, for Portugal we did not apply the Herfindahl index for the regional market of the loans, as the credit conditions are similar across the country. The analyses were performed using a difference-in-differences OLS regression for the balanced panel. Nonetheless, as the participation on the TLTRO was a choice of banks, the selection of the treatment group might present some endogeneity. However, the borrowing limit in these operations was a proportion of the stock of credit granted to nonfinancial corporations and households (except lending for house purchase) in a defined period before the TLTRO, so the identified endogeneity is therefore reduced. Furthermore, there might be confounding effects and endogeneity arising from the design of the policy itself that may affect the results. Therefore, the estimates should be interpreted having these caveats in mind.

First, we estimate the transmission of the TLTRO to the amount of credit granted by the banking sector to the real economy. We included time varying coefficients to capture the dynamics of the transmission of the TLTRO to the stock of credit and clustered the standard errors by bank. Therefore, the OLS empirical regression is:

$$
L_{b, t}=\alpha+\lambda_{b}+\phi \text { post }_{t}+\sum_{T} \beta_{T} \Phi_{T=t} T L T R O_{b, T}+\delta Y_{b, t-1}+\theta X_{b, t-1}+\epsilon_{b, t}
$$

where $L_{b, t}$ is the natural logarithm of the stock of credit of bank b, in period $\mathrm{t}, Y_{b, t-1}$ is the weighted average interest rate applied by bank b at time $\mathrm{t}$ in the previous month to new credit operations, $\lambda_{b}$ are bank fixed effects, post is a dummy equal to 1 when t corresponds to the TLTRO period, $\Phi_{T=t}$ is a dummy variable equal to 1 when t corresponds to year $\mathrm{i}(\mathrm{i}=2014,2015$, $2016,2017)$ and $\epsilon_{b, t}$ is an error term. These variables were complemented with time-varying control variables, deemed relevant to explain the stock of credit, representing bank individual characteristics that affect the dependent variable. Hence, $X_{b, t-1}$ are bank controls, namely the value of total assets, the loans over assets ratio, the bad loans over loans ratio and the government bonds over assets ratio. The amounts relate to the month prior to month $\mathrm{t}$.

The term $T L T R O_{b, t}$ is the treatment variable. First, we estimate a specification where the TLTRO variable is a dummy variable equal to one after the announcement of the policy if the bank has participated in the TLTRO, correspondent to the binary treatment. Second, we estimate an alternative specification with a continuous treatment, where the TLTRO variable, instead of a dummy, is the natural logarithm of the TLTRO outstanding amount, which measures the intensity of the treatment.

Second, we analyse the pass-through of the favourable interest rates of the TLTRO to the loan interest rates applied by banks to the real economy. We also include time varying coefficients to capture the dynamics of the transmission mechanism and cluster the standard errors by bank. The OLS 
empirical regression is:

$$
Y_{b, t}=\alpha+\lambda_{b}+\text { ppost }_{t}+\sum_{T} \beta_{T} \Phi_{T=t} \operatorname{TLTRO}_{b, T}+\theta X_{b, t-1}+\epsilon_{b, t}
$$

where $Y_{b, t}$ is the weighted average interest rate applied by bank $\mathrm{b}$, in period $\mathrm{t}$ in the previous month to new credit operations, $\lambda_{b}$ are bank fixed effects, post $_{t}$ is a dummy equal to 1 when t corresponds to the TLTRO period, TLTRO $O_{b, t}$ is the treatment variable, $\Phi_{T=t}$ is a dummy variable equal to 1 when $t$ corresponds to year $\mathrm{i}(\mathrm{i}=2014,2015,2016,2017)$ and $\epsilon_{b, t}$ is an error term. These variables were also complemented with the same time-varying control variables, $X_{b, t-1}$, such as the value of total assets, the loans over assets ratio, the bad loans over loans ratio and the government bonds over assets ratio. The amounts relate to the month prior to month $\mathrm{t}$.

\section{Results}

\subsection{Euro area}

6.1.1. The effects on the amount of credit. The first set of empirical results identifies the impact of the TLTRO on the stock of credit granted to the real economy. Table 5 shows the results for the OLS regression, controlling for bank fixed effects and clustered the standard errors by bank. Column (1) presents the results for all the Euro area banks, controlling for bank-specific characteristics. We do not find a statistically significant association between the TLTRO and credit granted to the real economy, even though there is some heterogeneity.

In columns (2) and (3), we divide the Euro area countries into less vulnerable and vulnerable countries. For the less vulnerable countries, the coefficients of the TLTRO outstanding are also not statistically significant. Nevertheless, for the vulnerable countries, the coefficients of the TLTRO are positive and statistically significant in 2016 and 2017. Thus, the results indicate that, in 2016 and 2017, banks in vulnerable countries used part of the money borrowed in the TLTRO to increase the credit granted to the real economy.

Moreover, the coefficient increases from 2016 to 2017, which means that the effects of the TLTRO may have increased in these years. Furthermore, the $R^{2}$ for vulnerable countries and small banks is much higher than in all the other specifications.

Additionally, we divide the sample of banks in the two groups of countries into large and small banks, assessed by its total assets. Thus, banks were considered as large banks if its amount of total assets was, on average, higher than or equal to EUR 1000 million and as small banks, otherwise.

Table 6 shows the results for the OLS regression, controlling for bank fixed effects and clustered the standard errors by bank. Columns (3) and (4) show that, in less vulnerable countries, TLTRO are positively associated with the stock of credit, although only marginally statistically significant for the 


\begin{tabular}{|c|c|c|c|}
\hline \multirow[b]{3}{*}{ VARIABLES } & \multicolumn{3}{|c|}{ Log of the stock of credit } \\
\hline & All countries & Less vulnerable countries & Vulnerable countries \\
\hline & $(1)$ & $(2)$ & (3) \\
\hline \multicolumn{4}{|l|}{$\log$ of TLTRO $\mathrm{x}$} \\
\hline \multirow[t]{2}{*}{2014} & -0.000133 & -0.000530 & 0.000004 \\
\hline & $(0.000276)$ & $(0.000758)$ & $(0.000003)$ \\
\hline \multirow[t]{2}{*}{2015} & 0.000097 & -0.000454 & 0.000006 \\
\hline & $(0.000251)$ & $(0.000929)$ & $(0.000004)$ \\
\hline \multirow[t]{2}{*}{2016} & 0.001095 & 0.001659 & $0.000014 * * *$ \\
\hline & $(0.000837)$ & $(0.001280)$ & $(0.000005)$ \\
\hline \multirow[t]{2}{*}{2017} & 0.001013 & 0.001571 & $0.000021 * * *$ \\
\hline & $(0.000791)$ & $(0.001252)$ & $(0.000007)$ \\
\hline Bank F.E. & YES & YES & YES \\
\hline Bank-time controls & YES & YES & YES \\
\hline Observations & 8641 & 6103 & 2538 \\
\hline $\mathrm{R}$-squared & 0.01 & 0.02 & 0.13 \\
\hline Number of banks & 749 & 540 & 209 \\
\hline
\end{tabular}

Standard errors in parentheses

$* * * \mathrm{p}<0.01, * * \mathrm{p}<0.05, * \mathrm{p}<0.1$

Table A.1 provides further information.

TABlE 5. Transmission of TLTRO liquidity to the stock of credit for the Euro area

Source: Banco de Portugal and authors' calculations.

small banks in 2014, 2015 and 2016. Columns (6) and (7) also show that the coefficients of the TLTRO are positive and statistically significant in 2016 and 2017 for both large and small banks located in vulnerable countries. For group of large banks in vulnerable countries, the coefficients are increasing from 2016 to 2017.

Furthermore, for the group of small banks, the effects are also increasing from 2016 to 2017 in vulnerable countries, as well as from 2014 to 2016 in less vulnerable countries and seem to be higher in less vulnerable countries, which indicates that the transmission worked better in these countries. The results also seem to suggest that, in vulnerable countries, the effects of the TLTRO were higher in small banks.

Nevertheless, the introduction of the APP in 2014 arises several confounding effects, which might be contributing to the reduced effects of the TLTRO on the stock of credit. In fact, the APP was the major responsible for the significant excess liquidity growth verified for the Euro area banks and therefore to increase the credit granted to the real economy (Andrade et al, 2016; Baldo et al, 2017).

The results for the Euro area suggest that the increase in the stock of credit illustrated in Figure 5 was in part explained by the liquidity injected through the TLTRO. Moreover, when splitting into vulnerable and less vulnerable countries, the results also show that the behaviour of the stock of credit illustrated in Figure 5, as well as in ECB (2017d), can also be in part explained by the TLTRO. The results also show a stronger correlation between the TLTRO and the stock of credit for less vulnerable countries, which is also in 


\begin{tabular}{|c|c|c|c|c|c|c|c|}
\hline & \multicolumn{7}{|c|}{ Log of the stock of credit } \\
\hline & \multirow{2}{*}{$\begin{array}{c}\text { All countries } \\
\text { All banks }\end{array}$} & \multicolumn{3}{|c|}{ Less vulnerable countries } & \multicolumn{3}{|c|}{ Vulnerable countries } \\
\hline & & All banks & Large banks & Small banks & All banks & Large banks & Small banks \\
\hline & (1) & (2) & (3) & (4) & (5) & (6) & (7) \\
\hline \multicolumn{8}{|l|}{$\log$ of TLTRO $\mathrm{x}$} \\
\hline \multirow[t]{2}{*}{2014} & -0.000133 & -0.000530 & -0.000712 & $0.001413^{*}$ & 0.000004 & 0.000002 & -0.000002 \\
\hline & $(0.000276)$ & $(0.000758)$ & $(0.000675)$ & $(0.000794)$ & $(0.000003)$ & $(0.000003)$ & $(0.000004)$ \\
\hline \multirow[t]{2}{*}{2015} & 0.000097 & -0.000454 & -0.000661 & $0.001622 *$ & 0.000006 & 0.000002 & 0.000008 \\
\hline & $(0.000251)$ & $(0.000929)$ & $(0.000931)$ & $(0.000902)$ & $(0.000004)$ & $(0.000004)$ & $(0.000005)$ \\
\hline \multirow[t]{2}{*}{2016} & 0.001095 & 0.001659 & 0.001789 & $0.001043 *$ & $0.000014 * * *$ & $0.000010 * *$ & $0.000017^{* * *}$ \\
\hline & $(0.000837)$ & $(0.001280)$ & $(0.001570)$ & $(0.000580)$ & $(0.000005)$ & $(0.000005)$ & $(0.000005)$ \\
\hline \multirow[t]{2}{*}{2017} & 0.001013 & 0.001571 & 0.001726 & 0.000691 & $0.000021 * * *$ & $0.000018^{* * *}$ & $0.000022 * * *$ \\
\hline & $(0.000791)$ & $(0.001252)$ & $(0.001513)$ & $(0.000420)$ & $(0.000007)$ & $(0.000007)$ & $(0.000005)$ \\
\hline Bank F.E. & YES & YES & YES & YES & YES & YES & YES \\
\hline Bank-time controls & YES & YES & YES & YES & YES & YES & YES \\
\hline Observations & 8641 & 6103 & 3467 & 2636 & 2538 & 1843 & 695 \\
\hline R-squared & 0.01 & 0.02 & 0.02 & 0.01 & 0.13 & 0.13 & 0.41 \\
\hline Number of banks & 749 & 540 & 290 & 250 & 209 & 143 & 66 \\
\hline
\end{tabular}

Standard errors in parentheses

*** $\mathrm{p}<0.01, * * \mathrm{p}<0.05, * \mathrm{p}<0.1$

Table A.2 provides further information.

TABLE 6. Transmission of TLTRO liquidity to the stock of credit, for large and small banks, for the Euro area

Source: Banco de Portugal and authors' calculations.

line with Figure 5 and ECB (2017d). Moreover, the results are also in line with the BLS, in which banks have mentioned that only used part of the liquidity borrowed from the TLTRO to grant credit (ECB, 2017a; ECB, 2017b). Therefore, even though of very small magnitude, the impact is estimated to be positive.

6.1.2. The effects of competition in the banking sector. The second set of empirical results identifies how the competition affects this transmission of the TLTRO to the stock of credit. The coefficient captures the interaction between the TLTRO and bank competition assessed by the Herfindahl Index of the country. Table 7 presents the results for the OLS regression, controlling for bank fixed effects and clustered the standard errors by bank. Hence, the results do not show a statistically significant role for market concentration on the transmission of the TLTRO to the stock of credit, as the effects are not statistically significant. Therefore, the estimates suggest that the transmission of the TLTRO to the real economy did not depend on market concentration in the banking sector. 


\begin{tabular}{|c|c|c|c|}
\hline \multirow[b]{3}{*}{ VARIABLES } & \multicolumn{3}{|c|}{ Log of the stock of credit } \\
\hline & All countries & Less vulnerable countries & Vulnerable countries \\
\hline & (1) & $(2)$ & (3) \\
\hline \multicolumn{4}{|l|}{$\log$ of TLTRO $x$} \\
\hline 2014 & $\begin{array}{l}-0.000280 \\
(0.000536)\end{array}$ & $\begin{array}{l}-0.000862 \\
(0.001187)\end{array}$ & $\begin{array}{c}0.000010 \\
(0.000007)\end{array}$ \\
\hline 2015 & $\begin{array}{l}-0.000185 \\
(0.000691)\end{array}$ & $\begin{array}{l}-0.000832 \\
(0.001452)\end{array}$ & $\begin{array}{c}0.000006 \\
(0.000005)\end{array}$ \\
\hline 2016 & $\begin{array}{c}0.001661 \\
(0.001280)\end{array}$ & $\begin{array}{c}0.002151 \\
(0.001671)\end{array}$ & $\begin{array}{c}0.000019^{* *} \\
(0.000007)\end{array}$ \\
\hline 2017 & $\begin{array}{r}0.001586 \\
(0.001273) \\
\end{array}$ & $\begin{array}{c}0.002053 \\
(0.001669) \\
\end{array}$ & $\begin{array}{c}0.000029 * * * \\
(0.000011) \\
\end{array}$ \\
\hline \multicolumn{4}{|c|}{$\log$ of TLTRO $x$ HI $x$} \\
\hline 2014 & $\begin{array}{c}0.000908 \\
(0.003020)\end{array}$ & $\begin{array}{c}0.004284 \\
(0.006419)\end{array}$ & $\begin{array}{l}-0.000083 \\
(0.000061)\end{array}$ \\
\hline 2015 & $\begin{array}{c}0.002554 \\
(0.005646)\end{array}$ & $\begin{array}{c}0.005482 \\
(0.008445)\end{array}$ & $\begin{array}{l}-0.000012 \\
(0.000039)\end{array}$ \\
\hline 2016 & $\begin{array}{l}-0.010631 \\
(0.008503)\end{array}$ & $\begin{array}{l}-0.010524 \\
(0.008622)\end{array}$ & $\begin{array}{l}-0.000074 \\
(0.000051)\end{array}$ \\
\hline 2017 & $\begin{array}{l}-0.010746 \\
(0.009126) \\
\end{array}$ & $\begin{array}{l}-0.010703 \\
(0.009440) \\
\end{array}$ & $\begin{array}{l}-0.000106 \\
(0.000076) \\
\end{array}$ \\
\hline Bank F.E. & YES & YES & YES \\
\hline Bank-time controls & YES & YES & YES \\
\hline Observations & 8641 & 6103 & 2538 \\
\hline R-squared & 0.01 & 0.02 & 0.14 \\
\hline Number of banks & 749 & 540 & 209 \\
\hline
\end{tabular}

Standard errors in parentheses

$* * * \mathrm{p}<0.01, * * \mathrm{p}<0.05, * \mathrm{p}<0.1$

Table A.3 provides further information.

TABLE 7. TLTRO and competition in the banking sector for the Euro area

Source: Banco de Portugal and authors' calculations.

\subsection{Portugal}

6.2.1. The effects on the amount of credit. The first set of empirical results identifies the correlation between the TLTRO and the stock of credit granted to the real economy, namely non-financial corporations and households (except lending for house purchase).

Table 8 presents the results on the effects of the TLTRO on the stock of credit granted, controlling for bank and time fixed effects and clustering the standard errors by bank. Column (1) shows the results for all Portuguese banks, but the effects are not statistically significant.

Additionally, we divide the Portuguese monetary policy counterparties sample in large and small banks, assessed by its total assets. Thus, banks were considered as large banks if its amount of total assets was, on average, higher than or equal to EUR 1000 million and as small banks, otherwise. Hence, both the treated group and the control group were adjusted accordingly to divide the sample into large and small banks. Among the 35 banks in the sample, 20 were classified as large banks, 12 of which have participated in the 


\begin{tabular}{|c|c|c|c|c|c|c|}
\hline \multirow[b]{4}{*}{ VARIABLES } & \multicolumn{6}{|c|}{ Log of the stock of credit } \\
\hline & \multicolumn{3}{|c|}{ Binary treatment } & \multicolumn{3}{|c|}{ Continuous treatment } \\
\hline & All banks & Large banks & Small banks & All banks & Large banks & Small banks \\
\hline & (1) & (2) & (3) & (4) & (5) & (6) \\
\hline \multicolumn{7}{|l|}{ TLTRO $\mathrm{x}$} \\
\hline 2014 & $\begin{array}{c}0.0615 \\
(0.0971)\end{array}$ & $\begin{array}{c}0.0004 \\
(0.1004)\end{array}$ & $\begin{array}{c}0.1642 \\
(0.1274)\end{array}$ & $\begin{array}{l}-0.0135 \\
(0.0140)\end{array}$ & $\begin{array}{c}0.0043 \\
(0.0111)\end{array}$ & $\begin{array}{c}0.0814 \\
(0.1349)\end{array}$ \\
\hline 2015 & $\begin{array}{c}0.1297 \\
(0.0829)\end{array}$ & $\begin{array}{c}0.0774 \\
(0.0714)\end{array}$ & $\begin{array}{c}0.2552 \\
(0.1892)\end{array}$ & $\begin{array}{l}-0.0099 \\
(0.0141)\end{array}$ & $\begin{array}{c}0.0041 \\
(0.0086)\end{array}$ & $\begin{array}{c}0.0607 \\
(0.1078)\end{array}$ \\
\hline 2016 & $\begin{array}{c}0.1037 \\
(0.1287)\end{array}$ & $\begin{array}{c}0.0482 \\
(0.0860)\end{array}$ & $\begin{array}{c}0.3208 \\
(0.3109)\end{array}$ & $\begin{array}{l}-0.0057 \\
(0.0135)\end{array}$ & $\begin{array}{c}0.0108 \\
(0.0083)\end{array}$ & $\begin{array}{c}0.0323 \\
(0.0984)\end{array}$ \\
\hline 2017 & $\begin{array}{c}0.1116 \\
(0.1258) \\
\end{array}$ & $\begin{array}{c}0.0871 \\
(0.0875) \\
\end{array}$ & $\begin{array}{c}0.2841 \\
(0.3371) \\
\end{array}$ & $\begin{array}{l}-0.0078 \\
(0.0127) \\
\end{array}$ & $\begin{array}{c}0.0125 \\
(0.0092) \\
\end{array}$ & $\begin{array}{l}-0.0349 \\
(0.0597) \\
\end{array}$ \\
\hline Bank F.E. & YES & YES & YES & YES & YES & YES \\
\hline Time F.E. & YES & YES & YES & YES & YES & YES \\
\hline Bank-time controls & YES & YES & YES & YES & YES & YES \\
\hline Observations & 2762 & 1597 & 1165 & 2762 & 1597 & 1165 \\
\hline R-squared & 0.38 & 0.16 & 0.39 & 0.37 & 0.16 & 0.39 \\
\hline Number of banks & 35 & 20 & 15 & 35 & 20 & 15 \\
\hline
\end{tabular}

Standard errors in parentheses

$* * * \mathrm{p}<0.01, * * \mathrm{p}<0.05, * \mathrm{p}<0.1$

Table A.4 provides further information.

TABLE 8. Transmission of TLTRO liquidity to the stock of credit for Portugal

Source: Banco de Portugal and authors' calculations.

TLTRO. The remaining 15 banks were considered small banks, 5 of which have participated in the TLTRO. Column (2) and (3) present the results for the sample of large banks and small banks, respectively, but the effects are not statistically significant.

In the continuous treatment case, we substitute the TLTRO dummy variable by the natural logarithm of the actual outstanding amount borrowed from the TLTRO. The results are also not statistically significant. Hence, the results suggest that there is no statistically significant association between the TLTRO and the amount of credit granted to the real economy. The lack of significant results might be explained by the implementation of the APP in 2014, which had a huge impact on excess liquidity amounts held by the Euro area banks and, consequently, on the stock of credit (Andrade et al, 2016; Baldo et al, 2017). According to Figure 6, in the last quarter of 2015 and again in the last quarter of 2017, non-bidder banks decreased the stock of credit, while bidder banks maintained the stock of credit relatively constant. This behaviour might be explained by a stronger effect of the APP in bidder banks, due its specific characteristics, for instance being, on average, larger banks, and not necessarily due to the liquidity injected through the TLTRO. Therefore, we cannot conclude about the transmission of the TLTRO to the amount of bank credit supply.

6.2.2. The effects on the cost of credit. The second set of empirical results identifies the correlation between the TLTRO and the cost of credit. We also 


\begin{tabular}{|c|c|c|c|c|c|c|}
\hline \multirow[b]{4}{*}{ VARIABLES } & \multicolumn{6}{|c|}{ Interest Rate } \\
\hline & \multicolumn{3}{|c|}{ Binary treatment } & \multicolumn{3}{|c|}{ Continuous treatment } \\
\hline & All banks & Large banks & Small banks & All banks & Large banks & Small banks \\
\hline & (1) & (2) & (3) & (4) & (5) & (6) \\
\hline \multicolumn{7}{|l|}{ TLTRO $\mathrm{x}$} \\
\hline \multirow{2}{*}{2014} & -0.1350 & $-0.6136 * *$ & -0.4080 & 0.0290 & -0.0285 & 0.4637 \\
\hline & $(0.1892)$ & $(0.2807)$ & $(0.5176)$ & $(0.0397)$ & $(0.0656)$ & $(0.4643)$ \\
\hline \multirow[t]{2}{*}{2015} & -0.3222 & $-0.9549 *$ & -0.6736 & $-0.0566^{*}$ & -0.1061 & -0.0591 \\
\hline & $(0.3107)$ & $(0.5105)$ & $(0.9266)$ & $(0.0335)$ & $(0.0650)$ & $(0.3111)$ \\
\hline \multirow[t]{2}{*}{2016} & $-1.1420 * * *$ & $-1.3370 * *$ & $-2.1078 * *$ & $-0.1366 * * *$ & $-0.1638^{* *}$ & -0.3131 \\
\hline & $(0.2729)$ & $(0.5037)$ & $(0.7719)$ & $(0.0326)$ & $(0.0620)$ & $(0.1902)$ \\
\hline \multirow[t]{2}{*}{2017} & $-1.6707 * * *$ & $-1.6292 * * *$ & $-2.9541 * * *$ & $-0.2121 * * *$ & $-0.2103 * * *$ & $-0.6608 * *$ \\
\hline & $(0.3429)$ & $(0.5371)$ & $(0.9541)$ & $(0.0389)$ & $(0.0664)$ & $(0.2853)$ \\
\hline Bank F.E. & YES & YES & YES & YES & YES & YES \\
\hline Time F.E. & YES & YES & YES & YES & YES & YES \\
\hline Bank-time controls & YES & YES & YES & YES & YES & YES \\
\hline Observations & 2762 & 1597 & 1165 & 2762 & 1597 & 1165 \\
\hline R-squared & 0.38 & 0.39 & 0.22 & 0.36 & 0.39 & 0.21 \\
\hline Number of banks & 35 & 20 & 15 & 35 & 20 & 15 \\
\hline
\end{tabular}

Standard errors in parentheses

$* * * \mathrm{p}<0.01, * * \mathrm{p}<0.05, * \mathrm{p}<0.1$

Table A.5 provides further information.

TABLE 9. Transmission of TLTRO liquidity to the cost of credit for Portugal Source: Banco de Portugal and authors' calculations.

estimate both specifications, the binary treatment, where the TLTRO variable is a dummy variable equal to one after the announcement of the policy if the bank has participated in the TLTRO, and the continuous treatment, measuring the intensity of the treatment, where the TLTRO variable is the natural logarithm of the TLTRO outstanding amount.

Table 9 presents the results on the effects of the TLTRO on the cost of credit, controlling for bank and time fixed effects and clustering the standard errors by bank. In column (1), we estimate the model on the full sample of banks and the effects are statistically significant. Treated banks decreased its loan rates relative to control banks and the effects are statistically significant in 2016 and 2017. In 2017, interest rates set by banks that have borrowed from the TLTRO are on average, approximately, 1.67 basis points lower relative to control banks.

We also divide the Portuguese monetary policy counterparties sample into large and small banks, assessed by the amount of its total assets. The effects of the TLTRO in the cost of credit was higher for small banks, suggesting a pass-through in these banks. In column (2), we estimate the OLS regression on the sample of large banks. The results are statistically significant for all the periods under analysis, verifying our previous conclusion of an increase in the effect of TLTRO along the years. In 2017, loan interest rates of treated banks were on average, approximately, 1.63 basis points lower relative to control banks. Finally, in column (3) we perform the same analysis for the small banks, showing that the effects of the TLTRO were higher for this group of banks 
when comparing treated and control banks. The results are only statistically significant in 2016 and 2017 and show that, in 2017, interest rates set by treated banks are on average, approximately, 2.95 basis points lower than those set by control banks.

In the continuous treatment, we substitute the TLTRO dummy variable by the natural logarithm of the TLTRO outstanding amounts. The results are only statistically significant in 2016 and 2017 and show that TLTRO had a positive impact on the cost of credit in these years. Similarly to the binary treatment, the impact was stronger on small banks.

Overall, the results suggest a positive and significant transmission of the TLTRO to the cost of credit in 2016 and 2017. Furthermore, the difference in the loan interest rates between treated and control banks increased since the beginning of the TLTRO, which could be explained by the introduction of the TLTRO-II in March 2016, which had the interest rate incentive and so the amount of net lending was used not only to determine the borrowing allowance, but also the interest rate applied to these operations, ranging from the MRO rate to the deposit facility rate (from $0 \%$ to $-0.4 \%$, respectively), which might led to a decrease in loan interest rates in order to increase the amount of credit granted to the real economy. These results suggest that the decrease in loan interest rates by treated banks illustrated in Figure 7 can be explained by the introduction of the TLTRO. Therefore, since its implementation in 2014, treated banks decreased its loan rates in relation to control banks, thereby reducing the difference between both groups of banks observed in the beginning of the TLTRO. The results on the effects of the TLTRO on the cost of credit suggest a correct functioning of monetary policy transmission mechanism, by the pass-through of the favourable interest rates applied in the TLTRO to the loan rates applied to the real economy.

The results on the functioning of the monetary policy transmission mechanism are in line with the existing literature, particularly the Balfoussia and Gibson (2015) analysis, which find an easing of the financial conditions resulted from the TLTRO, for both the Euro area and Greece and the Benetton and Fantino (2018) study, which find a decrease in loan interest rates by treated banks in relation to control banks, for the Italian case.

\section{Conclusion}

We have assessed the transmission of the unconventional monetary policy measures to bank credit supply, by studying the relationship between the TLTRO and the credit granted by the banking system to non-financial corporations and households (except lending for house purchase).

First, we perform an analysis for the Euro area, using an OLS empirical regression on a quarterly balanced panel. We find a positive correlation between the TLTRO and the stock of credit in 2016 and 2017 for the vulnerable countries 
and in 2014, 2015 and 2016 for the less vulnerable countries, which means that banks used part of the money borrowed in the TLTRO to grant credit to the real economy. We also find that, for the group of small banks, TLTRO had a higher impact in less vulnerable countries, showing that the transmission worked better in these countries. Additionally, we assessed how the competition in the banking sector affects the transmission of the TLTRO to the stock of credit, using the Herfindahl Index per country, which measures the market concentration of banking business. The results do not suggest a role of market concentration on the transmission of the TLTRO to the stock of credit.

Second, we perform a specific analysis for Portugal, using a difference-indifferences OLS regression on a monthly balanced panel. The results do not suggest a statistically significant impact of TLTRO on the amount of credit granted to the real economy. Regarding the effects of the TLTRO on credit conditions, we find a statistically significant association between the TLTRO and the cost of credit, indicating that treated banks set lower loan interest rates on average by, approximately, 1.67 basis points than control banks in 2017 . We also find that the difference between treated and control banks is higher for the group of small banks in terms of the cost of credit. Moreover, the effects of the TLTRO on loan interest rates increased during from 2016 to 2017, both in large and small banks.

The pass-through of TLTRO interest rates to loan interest rates characterises the correct functioning of monetary policy transmission mechanism, which is the aim of the monetary policy measures. Therefore, the results show that the TLTRO contributed to the well-functioning of the monetary policy transmission mechanism.

An interesting avenue for future research on the transmission of unconventional monetary policy to bank credit supply is the extension of the Euro area analysis, performing a similar analysis as the one for Portugal. This study requires additional data, to which we did not have had access to, namely for the period before the TLTRO and for the monetary policy counterparties that did not participate in the TLTRO (control group). Additionally, data on the interest rates would also be necessary, to infer the pass-through of the favourable interest rates applied to the TLTRO to loan interest rates. Using a difference-in-difference approach, we would be able to infer the evolution of both the amounts of credit granted and the loan interest rates of the banks that have participated in the TLTRO relative to the group of control banks. 


\section{References}

Acharya, V., Eisert, T., Eufinger, C. and Hirsch, C. (2012). Whatever it takes: The real effects of unconventional monetary policy. SAFE Working Paper Series 152.

Afonso, A., G. Arghyrou, M., Dolores Gadea, M. and Kontonikas, A. (2018). "Whatever it takes" to resolve the European sovereign debt crisis? Bond pricing regime switches and Monetary Policy effects. Journal of International Money and Finance 86, 1-30.

Afonso, A. and Kazemi, M. (2018). Euro Area Sovereign Yields and the Power of Unconventional Monetary Policy. Finance a Uver-Czech Journal of Economics and Finance 68 (2).

Agarwal, S., Chomsisengphet, S., Mahoney, N. and Stroebel, J. (2015). Do Banks Pass Through Credit Expansions? The Marginal Profitability of Consumer Lending During the Great Recession. NBER Working Paper 21567.

Andrade, P., Cahn, C., Fraisse, H. and Mésonnier, J. S. (2015). Can the provision of long-term liquidity help to avoid a credit crunch? Evidence from the Eurosystem's TLTROs. Banque de France Working Paper.

Angelopoulou, E., Balfoussia, H. and Gibson, H. (2013). Building a financial conditions index for the euro area and selected euro area countries: what does it tell us about the crisis? ECB Working Paper 1541.

Baldo, L., Hallinger B., Helmus, C., Herrala, N., Martins, D., Mohing, F., Petroulakis, F., Resinek, M., Vergote, O., Usciati, B. and Wang, Y. (2017). The distribution of excess liquidity in the Euro area. ECB Working Paper 200.

Balfoussia, H. and Gibson, H. D. (2015). Financial conditions and economic activity: the potential impact of the TLTROs. Bank of Greece Working Paper 194.

Baltagi, B. H. (2005). Econometric Analysis of Panel Data, 3rd Ed. England: John Wiley and Sons Ltd.

Banco de Portugal (2017). Decisões de política monetária desde o início da crise financeira. Relatório da Implementação da Política Monetária, December 2017, 14-15.

Benetton, M. and Fantino, D. (2018). Competition and the Pass-through of Unconventional Monetary Policy: Evidence from TLTROs. Banca D'Italia Working Paper 1187.

Berger, A. N. and Hannan, T. H. (1989). The Price-Concentration Relationship in Banking. The Review of Economics and Statistics 71 (2), 291299.

Carpinelli, L. and Crosignani, M. (2017). The Effect of Central Bank Liquidity Injections on Bank Credit Supply. Finance and Economics Discussion Series, 2017-038.

Chodorow-Reich, G. (2014). Effects of Unconventional Monetary Policy on Financial Institutions. Brookings Papers on Economic Activity, 155-204. 
Cottarelli, C., Ferri, G. and Generale, A. (1995). Bank Lending Rates and Financial Structure in Italy: A Case Study. IMF Staff Papers 42 (3), 670-700.

Darracq-Paries, M. and De Santis, R. (2013). A Non-standard Monetary Policy Shock: The ECB's 3-year LTROs and the Shift in Credit Supply. ECB Working Paper.

De Graeve, F., De Jonghe, O. and Vennet, R. Vander (2007). Competition, Transmission and Bank Pricing Policies: Evidence from Belgian Loan and Deposit Markets. Journal of Banking and Finance 31(1), 259-278.

Decision (EU) of the European Central Bank of 2 August 2012 on additional temporary measures relating to Eurosystem refinancing operations and eligibility of collateral and amending Guideline ECB/2007/9 (ECB/2012/18).

Decision (EU) of the European Central Bank of 4 April 2014 on monetary and financial statistics (ECB/2014/15).

Decision (EU) of the European Central Bank of 29 July 2014 on measures relating to targeted longer-term refinancing operations (ECB/2014/34).

Decision (EU) 2015/774 of the European Central Bank of 4 March 2015 on a secondary markets public sector asset purchase programme (ECB/2015/10).

Decision (EU) 2016/810 of the European Central Bank of 28 April 2016 on a second series of targeted longer-term refinancing operations (ECB/2016/10).

Di Maggio, M., Kermani, A. and Ramcharan, R. (2014). Monetary Policy Pass-Through: Household Consumption and Voluntary Deleveraging. Working Paper.

Draghi, M. (2014a). Introductory statement to the press conference (with QandA). Frankfurt am Main, Germany. July 4.

Draghi, M. (2014b). Safeguarding price and financial stability in the euro area. Helsinki, Finland. November 27.

Driffill, E. (2016). Unconventional Monetary Policy in the Euro Zone. Open Economies Review 27 (2), 387-404.

ECB (2014). Targeted Longer-Term Refinancing Operations: Guidelines for Completing the Reporting Template. Technical report.

ECB (2017a). Analysing the ECB's targeted long-term refinancing operations. The euro area bank lending survey, January 2017, 26-29.

ECB (2017b). Analysing the ECB's targeted long-term refinancing operations. The euro area bank lending survey, July 2017, 26-29.

ECB (2017c). Impact of the ECB's non-standard measures on financing conditions: taking stock of recent evidence. Economic Bulletin 2 (3), 46-51.

ECB (2017d). The targeted longer-term refinancing operations: an overview of the take-up and their impact on bank intermediation. Economic Bulletin 3 (5), 42-46.

Gertler, M. and Karadi, P. (2010). A model of unconventional monetary policy. Journal of Monetary Economics 58 (1), 17-34.

Chakraborty, I., Goldstein, I. and MacKinlay, A. (2016). Monetary Stimulus and Bank Lending. Working Paper. 
Jasova, M., Mendicino, C. and Supera, D. (2018). Rollover Risk and Bank Lending Behavior: Evidence from Unconventional Central Bank Liquidity. Working Paper.

Jiménez, G., Ongena, S. Peydró, J. L. and Saurina, J. (2012). Credit Supply and Monetary Policy: Identifying the Bank Balance-Sheet Channel with Loan Applications. The American Economic Review 102 (5), 2301-2326.

Jiménez, G., Ongena, S. Peydró, J. L. and Saurina, J. (2014). Hazardous Times for Monetary Policy: What Do Twenty-Three Million Bank Loans Say About the Effects of Monetary Policy on Credit Risk-Taking? Econometrica 82 (2), 463-505.

Kashyap, A. K. and Stein, J.C. (2000). What do a million observations on banks say about the transmission of monetary policy? American Economic Review 90, 407-428.

Khwaja, A. I. and Mian, A. (2008). Tracing the Impact of Bank Liquidity Shocks: Evidence from an Emerging Market. American Economic Review 98 (4), 1413-1442.

Mishkin, F. S. (2011). Monetary Policy Strategy: Lessons from the Crisis. NBER Working Paper 16755.

Neumark, D. and Sharpe, S. A. (1992). Market Structure and the Nature of Price Rigidity: Evidence from the Market for Consumer Deposits. The Quarterly Journal of Economics 107 (2), 657-680.

Renne, J. P. (2014). Options Embedded in ECB Targeted Refinancing Operations. Banque de France Working Paper.

Roman, A. and Purcel, D. (2014). The monetary policy under the impact of the recent global financial crisis. Review of Economic and Business Studies 7 (2), 179-188.

Schnabl, P. (2012). The International Transmission of Bank Liquidity Shocks: Evidence from an Emerging Market. The Journal of Finance 67 (3), 897-932.

Trichet, J. C. (2011). Unconventional Monetary Policy Measures: Principles - Conditions - Raison d'être, International Journal of Central Banking 9 (1), 229-250.

Van Leuvensteijn, M., Sorensen, C. K., Bikker, J. A. and van Rixtel, A. (2008). Impact of Bank Competition on the Interest Rate Pass-through in the Euro Area. ECB Working Paper 885. 


\section{Appendix: Figures and tables}

The table shows the estimated parameters and the standard errors for the OLS estimation of equation (1), from April 2014 to January 2018. Robust standard errors: clustered at the bank level in parenthesis.

\begin{tabular}{|c|c|c|c|}
\hline \multirow[b]{3}{*}{ VARIABLES } & \multicolumn{3}{|c|}{ Log of the stock of credit } \\
\hline & All countries & Less vulnerable countries & Vulnerable countries \\
\hline & (1) & $(2)$ & (3) \\
\hline \multicolumn{4}{|l|}{$\log$ of TLTRO $\mathrm{x}$} \\
\hline \multirow[t]{2}{*}{2014} & -0.000133 & -0.000530 & 0.000004 \\
\hline & $(0.000276)$ & $(0.000758)$ & $(0.000003)$ \\
\hline \multirow[t]{2}{*}{2015} & 0.000097 & -0.000454 & 0.000006 \\
\hline & $(0.000251)$ & $(0.000929)$ & $(0.000004)$ \\
\hline \multirow[t]{2}{*}{2016} & 0.001095 & 0.001659 & $0.000014 * * *$ \\
\hline & $(0.000837)$ & $(0.001280)$ & $(0.000005)$ \\
\hline \multirow[t]{2}{*}{2017} & 0.001013 & 0.001571 & $0.000021 * * *$ \\
\hline & $(0.000791)$ & $(0.001252)$ & $(0.000007)$ \\
\hline \multirow[t]{2}{*}{ Log of total assets } & -0.010059 & -0.019133 & $0.000649^{* * *}$ \\
\hline & $(0.011046)$ & $(0.021056)$ & $(0.000174)$ \\
\hline \multirow[t]{2}{*}{ Loans over assets ratio } & -0.000137 & -0.000379 & $0.000010^{* *}$ \\
\hline & $(0.000149)$ & $(0.000352)$ & $(0.000005)$ \\
\hline \multirow[t]{2}{*}{ Bad loans over loans ratio } & -0.000116 & 0.000160 & -0.000001 \\
\hline & $(0.000091)$ & $(0.000159)$ & $(0.000001)$ \\
\hline \multirow[t]{2}{*}{ Capital ratio } & 0.000037 & -0.000020 & 0.000005 \\
\hline & $(0.000151)$ & $(0.000259)$ & $(0.000005)$ \\
\hline \multirow[t]{2}{*}{ Constant } & $6.620874 * * *$ & $6.359898 * * *$ & $7.348251 * * *$ \\
\hline & $(0.093916)$ & $(0.178951)$ & $(0.001628)$ \\
\hline Bank F.E. & YES & YES & YES \\
\hline Bank-time controls & YES & YES & YES \\
\hline Observations & 8641 & 6103 & 2538 \\
\hline R-squared & 0.01 & 0.02 & 0.13 \\
\hline Number of banks & 749 & 540 & 209 \\
\hline
\end{tabular}

Standard errors in parentheses

$* * * \mathrm{p}<0.01, * * \mathrm{p}<0.05,{ }^{*} \mathrm{p}<0.1$

TABLE A.1. Transmission of TLTRO liquidity to the stock of credit for the Euro area 


\begin{tabular}{|c|c|c|c|c|c|c|c|}
\hline \multirow[b]{4}{*}{ VARIABLES } & \multicolumn{7}{|c|}{ Log of the stock of credit } \\
\hline & \multirow{2}{*}{$\begin{array}{c}\text { All countries } \\
\text { All banks } \\
\end{array}$} & \multicolumn{3}{|c|}{ Less vulnerable countries } & \multicolumn{3}{|c|}{ Vulnerable countries } \\
\hline & & All banks & Large banks & Small banks & All banks & Large banks & Small banks \\
\hline & (1) & (2) & (3) & (4) & (5) & (6) & (7) \\
\hline \multicolumn{8}{|l|}{$\log$ of TLTRO $x$} \\
\hline 2014 & $\begin{array}{l}-0.000133 \\
(0.000276)\end{array}$ & $\begin{array}{l}-0.000530 \\
(0.000758)\end{array}$ & $\begin{array}{l}-0.000712 \\
(0.000675)\end{array}$ & $\begin{array}{l}0.001413^{*} \\
(0.000794)\end{array}$ & $\begin{array}{c}0.000004 \\
(0.000003)\end{array}$ & $\begin{array}{c}0.000002 \\
(0.000003)\end{array}$ & $\begin{array}{c}-0.000002 \\
(0.000004)\end{array}$ \\
\hline 2015 & $\begin{array}{c}0.000097 \\
(0.000251)\end{array}$ & $\begin{array}{l}-0.000454 \\
(0.000929)\end{array}$ & $\begin{array}{l}-0.000661 \\
(0.000931)\end{array}$ & $\begin{array}{l}0.001622 * \\
(0.000902)\end{array}$ & $\begin{array}{c}0.000006 \\
(0.000004)\end{array}$ & $\begin{array}{c}0.000002 \\
(0.000004)\end{array}$ & $\begin{array}{c}0.000008 \\
(0.000005)\end{array}$ \\
\hline 2016 & $\begin{array}{c}0.001095 \\
(0.000837)\end{array}$ & $\begin{array}{c}0.001659 \\
(0.001280)\end{array}$ & $\begin{array}{c}0.001789 \\
(0.001570)\end{array}$ & $\begin{array}{l}0.001043^{*} \\
(0.000580)\end{array}$ & $\begin{array}{c}0.000014^{* * *} * \\
(0.000005)\end{array}$ & $\begin{array}{c}0.000010^{* *} \\
(0.000005)\end{array}$ & $\begin{array}{c}0.000017 * * * \\
(0.000005)\end{array}$ \\
\hline 2017 & $\begin{array}{c}0.001013 \\
(0.000791) \\
\end{array}$ & $\begin{array}{c}0.001571 \\
(0.001252) \\
\end{array}$ & $\begin{array}{c}0.001726 \\
(0.001513) \\
\end{array}$ & $\begin{array}{c}0.000691 \\
(0.000420) \\
\end{array}$ & $\begin{array}{c}0.000021^{* * *} \\
(0.000007) \\
\end{array}$ & $\begin{array}{c}0.000018^{* * *} \\
(0.000007) \\
\end{array}$ & $\begin{array}{c}0.000022^{* * *} \\
(0.000005) \\
\end{array}$ \\
\hline Log of total assets & $\begin{array}{l}-0.010059 \\
(0.011046)\end{array}$ & $\begin{array}{l}-0.019133 \\
(0.021056)\end{array}$ & $\begin{array}{l}-0.026252 \\
(0.027268)\end{array}$ & $\begin{array}{c}0.005995 \\
(0.007818)\end{array}$ & $\begin{array}{c}0.000649 * * * \\
(0.000174)\end{array}$ & $\begin{array}{c}0.000665^{* * *} * \\
(0.000228)\end{array}$ & $\begin{array}{c}0.000657^{* * *} * \\
(0.000151)\end{array}$ \\
\hline Loans over assets ratio & $\begin{array}{l}-0.000137 \\
(0.000149)\end{array}$ & $\begin{array}{l}-0.000379 \\
(0.000352)\end{array}$ & $\begin{array}{l}-0.000647 \\
(0.000561)\end{array}$ & $\begin{array}{c}0.000033 \\
(0.000242)\end{array}$ & $\begin{array}{c}0.000010^{* *} \\
(0.000005)\end{array}$ & $\begin{array}{c}0.000011^{* *} \\
(0.000006)\end{array}$ & $\begin{array}{c}0.000010^{* * *} * \\
(0.000003)\end{array}$ \\
\hline Bad loans over loans ratio & $\begin{array}{l}-0.000116 \\
(0.000091)\end{array}$ & $\begin{array}{c}0.000160 \\
(0.000159)\end{array}$ & $\begin{array}{c}0.000168 \\
(0.000324)\end{array}$ & $\begin{array}{c}0.000107 \\
(0.000128)\end{array}$ & $\begin{array}{l}-0.000001 \\
(0.000001)\end{array}$ & $\begin{array}{l}-0.000000 \\
(0.000001)\end{array}$ & $\begin{array}{l}-0.000000 \\
(0.000001)\end{array}$ \\
\hline Capital ratio & $\begin{array}{c}0.000037 \\
(0.000151)\end{array}$ & $\begin{array}{l}-0.000020 \\
(0.000259)\end{array}$ & $\begin{array}{l}-0.000091 \\
(0.000301)\end{array}$ & $\begin{array}{c}0.000215 \\
(0.000200)\end{array}$ & $\begin{array}{c}0.000005 \\
(0.000005)\end{array}$ & $\begin{array}{c}0.000004 \\
(0.000005)\end{array}$ & $\begin{array}{c}0.000003 \\
(0.000005)\end{array}$ \\
\hline Constant & $\begin{array}{c}6.620874^{* * *} * \\
(0.093916) \\
\end{array}$ & $\begin{array}{c}6.359898^{* * *} \\
(0.178951) \\
\end{array}$ & $\begin{array}{c}7.453454^{* * *} * \\
(0.266928) \\
\end{array}$ & $\begin{array}{c}4.844463^{* * *} \\
(0.040894) \\
\end{array}$ & $\begin{array}{c}7.348251 * * * \\
(0.001628) \\
\end{array}$ & $\begin{array}{c}8.067648^{* * *} * \\
(0.002287) \\
\end{array}$ & $\begin{array}{c}5.445451^{* * *} \\
(0.001046) \\
\end{array}$ \\
\hline Bank F.E. & YES & YES & YES & YES & YES & YES & YES \\
\hline Bank-time controls & YES & YES & YES & YES & YES & YES & YES \\
\hline Observations & 8641 & 6103 & 3467 & 2636 & 2538 & 1843 & 695 \\
\hline R-squared & 0.01 & 0.02 & 0.02 & 0.01 & 0.13 & 0.13 & 0.41 \\
\hline Number of banks & 749 & 540 & 290 & 250 & 209 & 143 & 66 \\
\hline
\end{tabular}

Standard errors in parentheses

$* * * \mathrm{p}<0.01,{ }^{* *} \mathrm{p}<0.05,{ }^{*} \mathrm{p}<0.1$

TABlE A.2. Transmission of TLTRO liquidity to the stock of credit, for large and small banks, for the Euro area

The table shows the estimated parameters and the standard errors for the OLS estimation of equation (1), from April 2014 to January 2018. The sample of banks in the two groups of countries was divided into large and small banks, assessed by its total assets: banks were considered as large banks if its amount of total assets was, on average, higher than or equal to EUR 1000 million and as small banks, otherwise. Robust standard errors: clustered at the bank level in parenthesis. 


\begin{tabular}{|c|c|c|c|}
\hline \multirow[b]{3}{*}{ VARIABLES } & \multicolumn{3}{|c|}{ Log of the stock of credit } \\
\hline & All countries & Less vulnerable countries & Vulnerable countries \\
\hline & $(1)$ & $(2)$ & (3) \\
\hline \multicolumn{4}{|l|}{$\log$ of TLTRO $\mathrm{x}$} \\
\hline \multirow[t]{2}{*}{2014} & -0.000280 & -0.000862 & 0.000010 \\
\hline & $(0.000536)$ & $(0.001187)$ & $(0.000007)$ \\
\hline \multirow[t]{2}{*}{2015} & -0.000185 & -0.000832 & 0.000006 \\
\hline & $(0.000691)$ & $(0.001452)$ & $(0.000005)$ \\
\hline \multirow[t]{2}{*}{2016} & 0.001661 & 0.002151 & $0.000019^{* *}$ \\
\hline & $(0.001280)$ & $(0.001671)$ & $(0.000007)$ \\
\hline \multirow[t]{2}{*}{2017} & 0.001586 & 0.002053 & $0.000029 * * *$ \\
\hline & $(0.001273)$ & $(0.001669)$ & $(0.000011)$ \\
\hline \multicolumn{4}{|l|}{$\log$ of TLTRO $x$ HI $x$} \\
\hline \multirow[t]{2}{*}{2014} & 0.000908 & 0.004284 & -0.000083 \\
\hline & $(0.003020)$ & $(0.006419)$ & $(0.000061)$ \\
\hline \multirow[t]{2}{*}{2015} & 0.002554 & 0.005482 & -0.000012 \\
\hline & $(0.005646)$ & $(0.008445)$ & $(0.000039)$ \\
\hline \multirow[t]{2}{*}{2016} & -0.010631 & -0.010524 & -0.000074 \\
\hline & $(0.008503)$ & $(0.008622)$ & $(0.000051)$ \\
\hline \multirow[t]{2}{*}{2017} & -0.010746 & -0.010703 & -0.000106 \\
\hline & $(0.009126)$ & $(0.009440)$ & $(0.000076)$ \\
\hline \multirow[t]{2}{*}{ Log of total assets } & -0.011738 & -0.020187 & $0.000644 * * *$ \\
\hline & $(0.012665)$ & $(0.022082)$ & $(0.000166)$ \\
\hline \multirow[t]{2}{*}{ Loans over assets ratio } & -0.000163 & -0.000398 & $0.000010^{* *}$ \\
\hline & $(0.000160)$ & $(0.000365)$ & $(0.000005)$ \\
\hline \multirow[t]{2}{*}{ Bad loans over loans ratio } & -0.000091 & 0.000175 & -0.000001 \\
\hline & $(0.000073)$ & $(0.000171)$ & $(0.000001)$ \\
\hline \multirow[t]{2}{*}{ Capital ratio } & 0.000001 & -0.000074 & 0.000005 \\
\hline & $(0.000181)$ & $(0.000301)$ & $(0.000005)$ \\
\hline \multirow[t]{2}{*}{ Constant } & $6.635999 * * *$ & $6.369800 * * *$ & $7.347056^{* * *}$ \\
\hline & $(0.107937)$ & $(0.188330)$ & $(0.001552)$ \\
\hline Bank F.E. & YES & YES & YES \\
\hline Bank-time controls & YES & YES & YES \\
\hline Observations & 8641 & 6103 & 2538 \\
\hline R-squared & 0.01 & 0.02 & 0.14 \\
\hline Number of banks & 749 & 540 & 209 \\
\hline
\end{tabular}

Standard errors in parentheses

$* * * \mathrm{p}<0.01, * * \mathrm{p}<0.05, * \mathrm{p}<0.1$

TABLE A.3. TLTRO and competition in the banking sector for the Euro area

The table shows the estimated parameters and the standard errors for the OLS estimation of equation (2), from April 2014 to January 2018. Robust standard errors: clustered at the bank level in parenthesis. 


\begin{tabular}{|c|c|c|c|c|c|c|}
\hline \multirow[b]{4}{*}{ VARIABLES } & \multicolumn{6}{|c|}{ Log of the stock of credit } \\
\hline & \multicolumn{3}{|c|}{ Binary treatment } & \multicolumn{3}{|c|}{ Continuous treatment } \\
\hline & All & Large banks & Small banks & All & Large banks & Small banks \\
\hline & (1) & (2) & (3) & (4) & (5) & (6) \\
\hline \multicolumn{7}{|l|}{ TLTRO $\mathrm{x}$} \\
\hline 2014 & $\begin{array}{c}0.0615 \\
(0.0971)\end{array}$ & $\begin{array}{c}0.0004 \\
(0.1004)\end{array}$ & $\begin{array}{c}0.1642 \\
(0.1274)\end{array}$ & $\begin{array}{l}-0.0135 \\
(0.0140)\end{array}$ & $\begin{array}{c}0.0043 \\
(0.0111)\end{array}$ & $\begin{array}{c}0.0814 \\
(0.1349)\end{array}$ \\
\hline 2015 & $\begin{array}{c}0.1297 \\
(0.0829)\end{array}$ & $\begin{array}{c}0.0774 \\
(0.0714)\end{array}$ & $\begin{array}{c}0.2552 \\
(0.1892)\end{array}$ & $\begin{array}{l}-0.0099 \\
(0.0141)\end{array}$ & $\begin{array}{c}0.0041 \\
(0.0086)\end{array}$ & $\begin{array}{c}0.0607 \\
(0.1078)\end{array}$ \\
\hline 2016 & $\begin{array}{c}0.1037 \\
(0.1287)\end{array}$ & $\begin{array}{c}0.0482 \\
(0.0860)\end{array}$ & $\begin{array}{c}0.3208 \\
(0.3109)\end{array}$ & $\begin{array}{c}-0.0057 \\
(0.0135)\end{array}$ & $\begin{array}{c}0.0108 \\
(0.0083)\end{array}$ & $\begin{array}{c}0.0323 \\
(0.0984)\end{array}$ \\
\hline 2017 & $\begin{array}{c}0.1116 \\
(0.1258) \\
\end{array}$ & $\begin{array}{c}0.0871 \\
(0.0875) \\
\end{array}$ & $\begin{array}{c}0.2841 \\
(0.3371) \\
\end{array}$ & $\begin{array}{r}-0.0078 \\
(0.0127) \\
\end{array}$ & $\begin{array}{c}0.0125 \\
(0.0092) \\
\end{array}$ & $\begin{array}{l}-0.0349 \\
(0.0597) \\
\end{array}$ \\
\hline Interest rate & $\begin{array}{c}0.0920 \\
(0.1133)\end{array}$ & $\begin{array}{c}0.0916 \\
(0.1008)\end{array}$ & $\begin{array}{c}0.2069 \\
(0.3225)\end{array}$ & $\begin{array}{c}-0.0118 \\
(0.0091)\end{array}$ & $\begin{array}{c}0.0227 \\
(0.0163)\end{array}$ & $\begin{array}{c}-0.0149^{*} \\
(0.0077)\end{array}$ \\
\hline Log of total assets & $\begin{array}{l}-0.0092 \\
(0.0090)\end{array}$ & $\begin{array}{c}0.0228 \\
(0.0157)\end{array}$ & $\begin{array}{l}-0.0111 \\
(0.0065)\end{array}$ & $\begin{array}{c}0.8629 * * * \\
(0.1399)\end{array}$ & $\begin{array}{c}0.4751^{* * *} \\
(0.1421)\end{array}$ & $\begin{array}{c}0.7060^{* * *} \\
(0.2357)\end{array}$ \\
\hline Loans over assets ratio & $\begin{array}{c}0.8503 * * * \\
(0.1369)\end{array}$ & $\begin{array}{c}0.4746 * * * \\
(0.1371)\end{array}$ & $\begin{array}{c}0.6530^{* *} \\
(0.2302)\end{array}$ & $\begin{array}{c}0.0095 * * \\
(0.0042)\end{array}$ & $\begin{array}{c}0.0147 * * * \\
(0.0036)\end{array}$ & $\begin{array}{c}0.0033 \\
(0.0060)\end{array}$ \\
\hline Bad loans over loans ratio & $\begin{array}{c}0.0096 * * \\
(0.0039)\end{array}$ & $\begin{array}{c}0.0148^{* * *} \\
(0.0036)\end{array}$ & $\begin{array}{c}0.0034 \\
(0.0059)\end{array}$ & $\begin{array}{l}-0.0027 \\
(0.0033)\end{array}$ & $\begin{array}{l}-0.0032 \\
(0.0096)\end{array}$ & $\begin{array}{c}0.0019 \\
(0.0052)\end{array}$ \\
\hline Government bonds over assets ratio & $\begin{array}{l}-0.0043 \\
(0.0033)\end{array}$ & $\begin{array}{c}-0.0048 \\
(0.0105)\end{array}$ & $\begin{array}{c}0.0022 \\
(0.0050)\end{array}$ & $\begin{array}{l}-0.0023 \\
(0.0035)\end{array}$ & $\begin{array}{l}-0.0012 \\
(0.0030)\end{array}$ & $\begin{array}{l}-0.0019 \\
(0.0035)\end{array}$ \\
\hline Post & $\begin{array}{l}-0.0020 \\
(0.0033)\end{array}$ & $\begin{array}{c}-0.0013 \\
(0.0030)\end{array}$ & $\begin{array}{c}-0.0013 \\
(0.0036)\end{array}$ & $\begin{array}{c}0.1369 \\
(0.0932)\end{array}$ & $\begin{array}{c}0.0100 \\
(0.0969)\end{array}$ & $\begin{array}{c}0.2375 \\
(0.1430)\end{array}$ \\
\hline Constant & $\begin{array}{r}-0.8193 \\
(1.2498) \\
\end{array}$ & $\begin{array}{l}2.3018^{*} \\
(1.2653)\end{array}$ & $\begin{array}{c}0.3766 \\
(1.3656) \\
\end{array}$ & $\begin{array}{r}-0.8944 \\
(1.2908) \\
\end{array}$ & $\begin{array}{l}2.3010^{*} \\
(1.3072)\end{array}$ & $\begin{array}{c}0.1081 \\
(1.4421) \\
\end{array}$ \\
\hline Bank F.E. & YES & YES & YES & YES & YES & YES \\
\hline Bank-time controls & YES & YES & YES & YES & YES & YES \\
\hline Observations & 2762 & 1597 & 1165 & 2762 & 1597 & 1165 \\
\hline R-squared & 0.38 & 0.16 & 0.39 & 0.37 & 0.16 & 0.39 \\
\hline Number of banks & 35 & 20 & 15 & 35 & 20 & 15 \\
\hline
\end{tabular}

Standard errors in parentheses

$* * * \mathrm{p}<0.01, * * \mathrm{p}<0.05, * \mathrm{p}<0.1$

TABLE A.4. Transmission of TLTRO liquidity to the stock of credit for Portugal

The table shows the estimated parameters and the standard errors for the OLS estimation of equation (3), from February 2011 to January 2018. The sample of banks in the two groups of countries was divided into large and small banks, assessed by its total assets: banks were considered as large banks if its amount of total assets was, on average, higher than or equal to EUR 1000 million and as small banks, otherwise. In the binary treatment, the TLTRO variable is a dummy variable equal to one after the announcement of the policy if the bank has participated in the TLTRO. The continuous treatment measures the intensity of the treatment, as the TLTRO variable is the natural logarithm of the TLTRO outstanding amount. Robust standard errors: clustered at the bank level in parenthesis. 


\begin{tabular}{|c|c|c|c|c|c|c|}
\hline \multirow[b]{4}{*}{ VARIABLES } & \multicolumn{6}{|c|}{ Interest Rate } \\
\hline & \multicolumn{3}{|c|}{ Binary treatment } & \multicolumn{3}{|c|}{ Continuous treatment } \\
\hline & All & Large banks & Small banks & All & Large banks & Small banks \\
\hline & (1) & (2) & (3) & (4) & (5) & (6) \\
\hline \multicolumn{7}{|l|}{ TLTRO $\mathrm{x}$} \\
\hline 2014 & $\begin{array}{l}-0.1350 \\
(0.1892)\end{array}$ & $\begin{array}{c}-0.6136^{* *} \\
(0.2807)\end{array}$ & $\begin{array}{c}-0.4080 \\
(0.5176)\end{array}$ & $\begin{array}{c}0.0290 \\
(0.0397)\end{array}$ & $\begin{array}{l}-0.0285 \\
(0.0656)\end{array}$ & $\begin{array}{c}0.4637 \\
(0.4643)\end{array}$ \\
\hline 2015 & $\begin{array}{l}-0.3222 \\
(0.3107)\end{array}$ & $\begin{array}{l}-0.9549^{*} \\
(0.5105)\end{array}$ & $\begin{array}{l}-0.6736 \\
(0.9266)\end{array}$ & $\begin{array}{l}-0.0566^{*} \\
(0.0335)\end{array}$ & $\begin{array}{l}-0.1061 \\
(0.0650)\end{array}$ & $\begin{array}{l}-0.0591 \\
(0.3111)\end{array}$ \\
\hline 2016 & $\begin{array}{c}-1.1420^{* * *} \\
(0.2729)\end{array}$ & $\begin{array}{c}-1.3370^{* *} \\
(0.5037)\end{array}$ & $\begin{array}{c}-2.1078 * * \\
(0.7719)\end{array}$ & $\begin{array}{c}-0.1366 * * * \\
(0.0326)\end{array}$ & $\begin{array}{c}-0.1638 * * \\
(0.0620)\end{array}$ & $\begin{array}{l}-0.3131 \\
(0.1902)\end{array}$ \\
\hline 2017 & $\begin{array}{c}-1.6707 * * * \\
(0.3429) \\
\end{array}$ & $\begin{array}{c}-1.6292^{* * *} \\
(0.5371) \\
\end{array}$ & $\begin{array}{c}-2.9541^{* * *} \\
(0.9541) \\
\end{array}$ & $\begin{array}{c}-0.2121 * * * \\
(0.0389) \\
\end{array}$ & $\begin{array}{c}-0.2103^{* * *} \\
(0.0664) \\
\end{array}$ & $\begin{array}{c}-0.6608^{* *} \\
(0.2853) \\
\end{array}$ \\
\hline Log of total assets & $\begin{array}{c}0.2201 \\
(0.2146)\end{array}$ & $\begin{array}{c}0.2985 \\
(0.7370)\end{array}$ & $\begin{array}{c}0.8540^{* *} \\
(0.3978)\end{array}$ & $\begin{array}{c}0.0959 \\
(0.2231)\end{array}$ & $\begin{array}{c}0.2520 \\
(0.7443)\end{array}$ & $\begin{array}{c}0.6791 \\
(0.4559)\end{array}$ \\
\hline Loans over assets ratio & $\begin{array}{c}0.0090 \\
(0.0076)\end{array}$ & $\begin{array}{l}0.0372^{*} \\
(0.0204)\end{array}$ & $\begin{array}{c}0.0165 \\
(0.0096)\end{array}$ & $\begin{array}{c}0.0084 \\
(0.0073)\end{array}$ & $\begin{array}{l}0.0378^{*} \\
(0.0209)\end{array}$ & $\begin{array}{c}0.0132 \\
(0.0091)\end{array}$ \\
\hline Bad loans over loans ratio & $\begin{array}{c}0.0417^{* *} \\
(0.0168)\end{array}$ & $\begin{array}{c}0.1310 \\
(0.0953)\end{array}$ & $\begin{array}{c}0.0058 \\
(0.0141)\end{array}$ & $\begin{array}{c}0.0464 * * \\
(0.0208)\end{array}$ & $\begin{array}{c}0.1184 \\
(0.0929)\end{array}$ & $\begin{array}{c}0.0077 \\
(0.0154)\end{array}$ \\
\hline Government bonds over assets ratio & $\begin{array}{l}-0.0135^{*} \\
(0.0070) \\
\end{array}$ & $\begin{array}{r}-0.0039 \\
(0.0097) \\
\end{array}$ & $\begin{array}{l}-0.0079 \\
(0.0124) \\
\end{array}$ & $\begin{array}{l}-0.0123 \\
(0.0078) \\
\end{array}$ & $\begin{array}{l}-0.0030 \\
(0.0099) \\
\end{array}$ & $\begin{array}{l}-0.0050 \\
(0.0142)\end{array}$ \\
\hline Post & $\begin{array}{c}-1.5412^{* * *} \\
(0.2149)\end{array}$ & $\begin{array}{c}-1.2012^{* *} \\
(0.4838)\end{array}$ & $\begin{array}{c}-1.5714 * * * \\
(0.4275)\end{array}$ & $\begin{array}{c}-1.7032 * * * \\
(0.2284)\end{array}$ & $\begin{array}{c}-1.3793^{* * *} \\
(0.4400)\end{array}$ & $\begin{array}{c}-1.9542^{* * *} \\
(0.4505)\end{array}$ \\
\hline Constant & $\begin{array}{c}3.6933^{* *} \\
(1.7314) \\
\end{array}$ & $\begin{array}{r}-0.8884 \\
(7.8469) \\
\end{array}$ & $\begin{array}{r}-0.5944 \\
(2.1339) \\
\end{array}$ & $\begin{array}{c}4.6818^{* *} \\
(1.8636) \\
\end{array}$ & $\begin{array}{l}-0.5080 \\
(7.8629) \\
\end{array}$ & $\begin{array}{c}0.5990 \\
(2.5235) \\
\end{array}$ \\
\hline Bank F.E. & YES & YES & YES & YES & YES & YES \\
\hline Bank-time controls & YES & YES & YES & YES & YES & YES \\
\hline Observations & 2762 & 1597 & 1165 & 2762 & 1597 & 1165 \\
\hline R-squared & 0.38 & 0.39 & 0.22 & 0.36 & 0.39 & 0.21 \\
\hline Number of banks & 35 & 20 & 15 & 35 & 20 & 15 \\
\hline
\end{tabular}

Standard errors in parentheses

$* * * \mathrm{p}<0.01, * * \mathrm{p}<0.05, * \mathrm{p}<0.1$

TABle A.5. Transmission of TLTRO liquidity to the cost of credit for Portugal

The table shows the estimated parameters and the standard errors for the OLS estimation of equation (4), from February 2011 to January 2018. The sample of banks in the two groups of countries was divided into large and small banks, assessed by its total assets: banks were considered as large banks if its amount of total assets was, on average, higher than or equal to EUR 1000 million and as small banks, otherwise. In the binary treatment, the TLTRO variable is a dummy variable equal to one after the announcement of the policy if the bank has participated in the TLTRO. The continuous treatment measures the intensity of the treatment, as the TLTRO variable is the natural logarithm of the TLTRO outstanding amount. Robust standard errors: clustered at the bank level in parenthesis. 


\section{Working Papers}

\section{7}

1|17 The diffusion of knowledge via managers' mobility

Giordano Mion | Luca David Opromolla | Alessandro Sforza

2|17 Upward nominal wage rigidity

Paulo Guimarães | Fernando Martins | Pedro Portugal

3|17 Zooming the ins and outs of the U.S. unemployment

Pedro Portugal | António Rua

4|17 Labor market imperfections and the firm's wage setting policy

Sónia Félix | Pedro Portugal

5|17 International banking and cross-border effects of regulation: lessons from Portugal

Diana Bonfim | Sónia Costa

6|17 Disentangling the channels from birthdate to educational attainment

Luís Martins | Manuel Coutinho Pereira

7|17 Who's who in global value chains? A weighted network approach

João Amador | Sónia Cabral | Rossana Mastrandrea | Franco Ruzzenenti

8|17 Lending relationships and the real economy: evidence in the context of the euro area sovereign debt crisis

Luciana Barbosa
9|17 Impact of uncertainty measures on the Portuguese economy

Cristina Manteu | Sara Serra

10|17 Modelling currency demand in a small open economy within a monetary union

António Rua

11|17 Boom, slump, sudden stops, recovery, and policy options. Portugal and the Euro Olivier Blanchard | Pedro Portugal

12|17 Inefficiency distribution of the European Banking System

João Oliveira

13|17 Banks' liquidity management and systemic risk

Luca G. Deidda | Ettore Panetti

14|17 Entrepreneurial risk and diversification through trade

Federico Esposito

15|17 The portuguese post-2008 period: a narrative from an estimated DSGE model

Paulo Júlio | José R. Maria

16|17 A theory of government bailouts in a heterogeneous banking system

Filomena Garcia | Ettore Panetti

17|17 Goods and factor market integration: a quantitative assessment of the EU enlargement FLorenzo Caliendo | Luca David Opromolla | Fernando Parro | Alessandro Sforza 


\section{8}

1|18 Calibration and the estimation of macroeconomic models

Nikolay Iskrev

2|18 Are asset price data informative about news shocks? A DSGE perspective

Nikolay Iskrey

3|18 Sub-optimality of the friedman rule with distorting taxes

Bernardino Adão | André C. Silva

4|18 The effect of firm cash holdings on monetary policy

Bernardino Adão | André C. Silva

5|18 The returns to schooling unveiled Ana Rute Cardoso | Paulo Guimarães | Pedro Portugal | Hugo Reis

$6 \mid 18$ Real effects of financial distress: the role of heterogeneity

Francisco Buera | Sudipto Karmakar

7|18 Did recent reforms facilitate EU labour market adjustment? Firm level evidence Mario Izquierdo | Theodora Kosma | Ana Lamo | Fernando Martins | Simon Savsek

$8 \mid 18$ Flexible wage components as a source of wage adaptability to shocks: evidence from European firms, 2010-2013

Jan Babecký | Clémence Berson | Ludmila Fadejeva | Ana Lamo | Petra Marotzke Fernando Martins | Pawel Strzelecki

9|18 The effects of official and unofficial information on tax compliance

Filomena Garcia | Luca David Opromolla Andrea Vezulli | Rafael Marques
10|18 International trade in services: evidence for portuguese firms

João Amador | Sónia Cabral | Birgitte Ringstad

11|18 Fear the walking dead: zombie firms, spillovers and exit barriers

Ana Fontoura Gouveia | Christian Osterhold

12|18 Collateral Damage? Labour Market Effects of Competing with China - at Home and Abroad

Sónia Cabral | Pedro S. Martins | João Pereira dos Santos | Mariana Tavares

13|18 An integrated financial amplifier: The role of defaulted loans and occasionally binding constraints in output fluctuations

Paulo Júlio | José R. Maria

14|18 Structural Changes in the Duration of Bull Markets and Business Cycle Dynamics

João Cruz | João Nicolau | Paulo M.M. Rodrigues

15|18 Cross-border spillovers of monetary policy: what changes during a financial crisis?

Luciana Barbosa | Diana Bonfim | Sónia Costa | Mary Everett

16|18 When losses turn into loans: the cost of undercapitalized banks

Laura Blattner | Luísa Farinha | Francisca Rebelo

17|18 Testing the fractionally integrated hypothesis using M estimation: With an application to stock market volatility

Matei Demetrescu | Paulo M. M. Rodrigues | Antonio Rubia 
18|18 Every cloud has a silver lining: Micro-level evidence on the cleansing effects of the Portuguese financial crisis

Daniel A. Dias | Carlos Robalo Marques

19|18 To ask or not to ask? Collateral versus screening in lending relationships

Hans Degryse | Artashes Karapetyan | Sudipto Karmakar

20|18 Thirty years of economic growth in Africa João Amador | António R. dos Santos

21|18 CEO performance in severe crises: the role of newcomers

Sharmin Sazedj | João Amador | José Tavares

22|18 A general equilibrium theory of occupational choice under optimistic beliefs about entrepreneurial ability Michele Dell'Era | Luca David Opromolla | Luís Santos-Pinto

\section{9}

1|19 The transmission of unconventional monetary policy to bank credit supply: evidence from the TLTRO

António Afonso | Joana Sousa-Leite
23|18 Exploring the implications of different loanto-value macroprudential policy designs Rita Basto | Sandra Gomes | Diana Lima

24|18 Bank shocks and firm performance: new evidence from the sovereign debt crisis Luísa Farinha | Marina-Eliza Spaliara | Serafem Tsoukas

25|18 Bank credit allocation and productivity: stylised facts for Portugal Nuno Azevedo | Márcio Mateus | Álvaro Pina

26|18 Does domestic demand matter for firms' exports?

Paulo Soares Esteves | Miguel Portela | António Rua

27|18 Credit Subsidies Isabel Correia | Fiorella De Fiore | Pedro Teles | Oreste Tristani 
www.bportugal.pt 